\title{
Heart failure in congenital heart disease: A review of clinical status and meta-analysis of diagnostic value of serum natriuretic peptides, and medical and device therapies
}

\author{
Aref Albakri* \\ St-Marien hospital Bonn Venusberg, Department of Internal Medicine, Bonn, Germany
}

\begin{abstract}
Traditional description of heart failure (HF) has been within the context of ischemic, hypertensive, valvular and myopathic disease. This description has contributed to the under-appreciation of $\mathrm{HF}$ in adult patients with congenital heart disease (CHD), who also manifest all the pathophysiological criteria constituting the clinical syndrome of HF. In adult CHD patients, heterogeneity of residual substrates predisposes them to an early development of HF, presenting a unique challenge in both categorization and protocol management of HF. As such, current diagnosis and treatment using consensus guidelines developed for HF in general remains unclear if they can serve as a meaningful framework for these patients. In this systematic review and meta-analysis, we review current evidence of this rare but life threatening form of HF affecting a large and growing number of adults. The discussion centers on clinical definition, epidemiology, pathophysiology, diagnosis and management with the view of advancing knowledge of the clinical status of HF in CHD.
\end{abstract}

\begin{abstract}
Abbreviation: ACE-I: angiotensin converting enzyme inhibitor; AHA: american heart association; ANP: atrial natriuretic peptide; ARBs: angiotensin receptor blockers; AS: aortic stenosis; ASD: atrial septal defect; AVSD: atrioventricular septal defect; BAV: bicuspid aortic valves; BNP: b-type natriuretic peptide; CHD: congenital heart disease; CHF: congenital heart failure; CKD: chronic kidney disease; CPET: cardiopulmonary exercise test; CRT: cardiac resynchronization therapy; ECG: electrocardiogram; ESC: european society of cardiology; ICD: implantable cardioverter defibrillator; LVNC: left ventricular non-compaction; LVOT: left ventricular outflow tract; MRA: mineralocorticoid receptor antagonist; MRI: magnetic resonance imaging; NPs: natriuretic peptides; NT-proBNP: n-terminal probnp; NYHA: new york heart association; PAP: pulmonary artery pressure; PLE: protein loosing enteropathy; RAAS: renin-angiotensinaldosterone system; RVOT: right ventricular outflow tract; SCD: sudden cardiac death; TGA: transposition of the great arteries; TR: tricuspid regurgitation; VSD: ventricular septal defect.
\end{abstract}

\section{Introduction}

Heart failure (HF) is the final common pathway of various cardiac pathologies. However, the traditional description of HF within the context of ischemic, hypertensive, valvular and myopathic diseases contributed to the present under-appreciation of an important subpopulation of HF patients, those with (corrected) congenital heart diseases (CHD), who go on to fulfill all the pathophysiological criteria for HF [1]. The under-appreciation is evident on the 32nd Bethesda Conference report in 2000 on "Care of the Adult with Congenital Heart Disease" [2] attesting to a largely an unmet delivery of appropriate evidence-based and guideline-directed care to CHD patients with HF. The report recommended organizing specialized care centers for $\mathrm{CHD}$ patients to disseminate care, provide education, motivate research and innovation, and serve as a general resource center. Such a specialized care system has been demonstrated to achieve uniformity of care and better clinical outcomes within guidelines framework for adult patients with other chronic severe illnesses such as cancer [2]. Besides the Bethesda Conference report, another significant factor driving increased research recognition of $\mathrm{HF}$ in $\mathrm{CHD}$ patients is the changing epidemiology in the CHD population, which however, has not had a matching proportional expansion in research and in public health practices [3].

The epidemiological shift in CHD patients characterized by an increasing adult population, has been observed over the past six decades as a result of significant advancements in both diagnosis and treatment considerably improving long-term clinical outcomes and leading to unprecedented survival rates $[3,4]$. The impact of this cumulative survival has put more adult CHD patients at an elevated risk for early development of HF because adult survivors often exhibit residual cardiac or hepatic abnormalities resulting from a sequela of cardiac dysfunction [5,6]. Despite therapeutic success for CHD patients, the 2016 American Heart Association (AHA) scientific statement on congestive $\mathrm{HF}(\mathrm{CHF})$ in $\mathrm{CHD}$ patients [7] indicates many therapies for CHD are mainly palliative rather than curative and that $\mathrm{CHD}$ patients remain at an elevated risk of developing HF. Moreover,

*Correspondence to: Aref Albakri, St-Marien hospital Bonn Venusberg, Department of Internal Medicine, Bonn, Germany, E-mail: arefalbakri@yahoo.com

Key words: congenital heart disease, heart failure

Received: October 01, 2018; Accepted: October 15, 2018; Published: October 17,2018 
clinical management of HF in CHD is complicated by a wide range in the ages of its initial clinical occurrence, heterogeneity of underlying cardiac morphology, a broad spectrum of causes, the lack of validated biomarkers for both prognosis and monitoring, reliable risk factors, and inadequate evidence demonstrating treatment efficacy [7]. Thus, the purpose of this systematic review and meta-analysis is to appraise available published peer-reviewed evidence pertaining to HF in CHD with the intention of highlighting important gaps in knowledge and inspiring the need for studies focused on HF mechanisms and improvement of clinical outcomes of HF in CHD patients.

\section{Definition}

CHD is a clinical term encompassing all structural malformations of the heart or intrathoracic great vessels of actual or potential functional significance that occur in utero and exist at birth [8]. Some cardiac defects such as persistent left superior vena cava or inferior vena cava-azygous continuity are trivial or correct spontaneously and thus usually excluded as typical forms of HF-associated CHD $[9,10]$. In some studies, CHD has been classified into two conditions: acyanotic CHD characterized by obstructive stenosis or left-to-right shunts, and cyanotic CHD characterized by low blood oxygen levels [11]. Typical examples of acyanotic conditions are atrial septal defect, ventricular septal defect, patent ductus arteriosus, pulmonary stenosis, aortic stenosis, and coarctation of the aorta. Typical examples of cyanotic conditions are tetralogy of Fallot (ToF), transposition of the great arteries (TGA), tricuspid atresia, total anomalous pulmonary venous connection, truncus arteriosus, double-outlet right ventricle, interrupted aortic arch, double-inlet left ventricle, and absent pulmonary valve syndrome [3].

Although CHD-related cardiac defect when surgically corrected at childhood improves survival, adult patients often remain with residual cardiac abnormalities, which predisposes them to an early development of the clinical syndrome of HF. In adult CHD, complex cardiac defects requiring regular observation at adult $\mathrm{CHD}$ centers include valved and non-valved conduits, double-outlet ventricle, cyanotic congenital heart, Eisenmenger syndrome, Fontan procedure, mitral atresia, pulmonary atresia, pulmonary vascular obstructive disease, transposition of the great arteries (TGA), tricuspid atresia, and truncus arteriosus/ hemitruncus [11]. Ultimately, adult CHD can progress to HF, defined as the inability of the heart to pump sufficient blood to meet the body's metabolic needs, as consequence of a confluence between complex genetic factors and acquired stressors caused by an underlying cardiac defect [12].

\section{Epidemiology}

Several population-based studies have provided valuable data on the incidence and prevalence of both pediatric and adult CHD, altogether demonstrating a tendency towards increasing burden of adult CHD with an increased risk of developing HF [8,13-15]. In an analysis of pre-natal diagnosis of congenital cardiac malformations by fetal echocardiography in a birth population $(n=1,589)$, the estimated incidence of CHD was 8.1 per 1,000 live births [8]. The prevalence of complex and hemodynamically significant stenosis, which if left untreated via surgical or percutaneous methods could lead to early death, is 2.3 per 1,000 infants [13]. Over the past six decades, considerable progress in pediatric cardiology and cardiac surgery has significantly increased the population of CHD pediatric patients surviving to adulthood from $15 \%$ in the 1960 s to the $85 \%$ in 2008 [14]. Consequently, the prevalence of adult CHD has surpassed that of pediatric population with CHD in the Unites States $[13,15]$. In support, a population-based cohort study of 71,686 CHD patients in Canada from 1987 to 2005 reported infant-CHD morality decreased significantly with a shifting mortality burden towards adults with CHD (18-64 years) [16]. HF is emerging as a major health problem in adults with CHD because almost $25 \%$ of them develop HF after three decades of life [17]. In the Dutch National 'CONCOR' registry, the incidence of first HF-admission in adult CHD cohort was 1.2 per 1,000 patient years [18].

\section{Pathophysiology}

The pathophysiology of HF in CHD patients has been hypothesized to occur in three main pathways: (a) acquired (non-genetic) HF; (b) genetic component causing cardiac malformations and cardiomyopathy leading to HF (not related to hemodynamic stress); and (c) a confluence of congenital genetic elements and acquired hemodynamic stressors (Figure 1).

\section{Non-genetic pathway}

Non-genetic or acquired pathway in the progression of CHD to HF describes accumulative myocardial insult primarily due to abnormalities in cardiac structure present at birth leading to the development of HF later in life. Non-genetic pathway is purely an acquired form of HF in the absence of a genetic component. The underlying etiology usually includes CHD-associated gross structural malformations such as significant lesions, which affect the ability of the heart to act as a pump. Mostly, incomplete or palliative correction of lesion can lead to a chronic state of hemodynamic stress and consequently HF. The probability of HF in CHD lesions such as tetralogy of and the transposition of the great arteries (TGA) is as high as $80 \%$ at the fifth decade of life, and about 20 to $30 \%$ for isolated valvular heart disease or defects leading to leftto-right shunting [18]. Additional insults to the myocardium that can complicate surgery include injury to the myocardium, coronary arteries and/or conduction system [12]. In some CHD patients, post-surgical conduction disease requiring permanent ventricular pacing can lead to progressive contractile dysfunction. These insults to the myocardium occur in the first years of life and the effect of altered hemodynamics (volume or pressure overload) or myocardial injury accumulate over the years increasing the risk of early development of HF [18].

\section{Genetic pathway}

Genetic basis of CHD has been suggested as another pathway for the progression of $\mathrm{CHD}$ to $\mathrm{HF}$ but its application in clinical practice remains limited. Genetic involvement in CHD accounts for about 5-10\% of HF related to the loss of function, mutations in transcription factor genes and other signaling molecules that perturb molecular pathways during cardiac development in utero [20]. Genetic basis is associated with development of cardiac malformations and cardiomyopathy ultimately leading to HF in the absence of hemodynamic stress, which is the hallmark in the non-genetic pathway. Genetic basis for HF in $\mathrm{CHD}$ patients begins during cardiac development in utero where certain molecular perturbations cause cardiac defect at birth and cardiomyopathy that can present later in life [12].

Genetic basis of HF in CHD has been observed in syndromic cases where $\mathrm{CHD}$ occurs with non-cardiac congenital malformations. Genetic testing in syndromic CHD has identified mutations that can lead to CHD. For instance, in Holt-Oram Syndrome, mutations in TEX5 and SALL4 genes cause CHD and upper limb malformations while in Alagille Syndrome, mutations in JAG1 or NOTCH2 genes cause CHD and liver disease. For non-syndromic CHD, clinical genetic testing is 


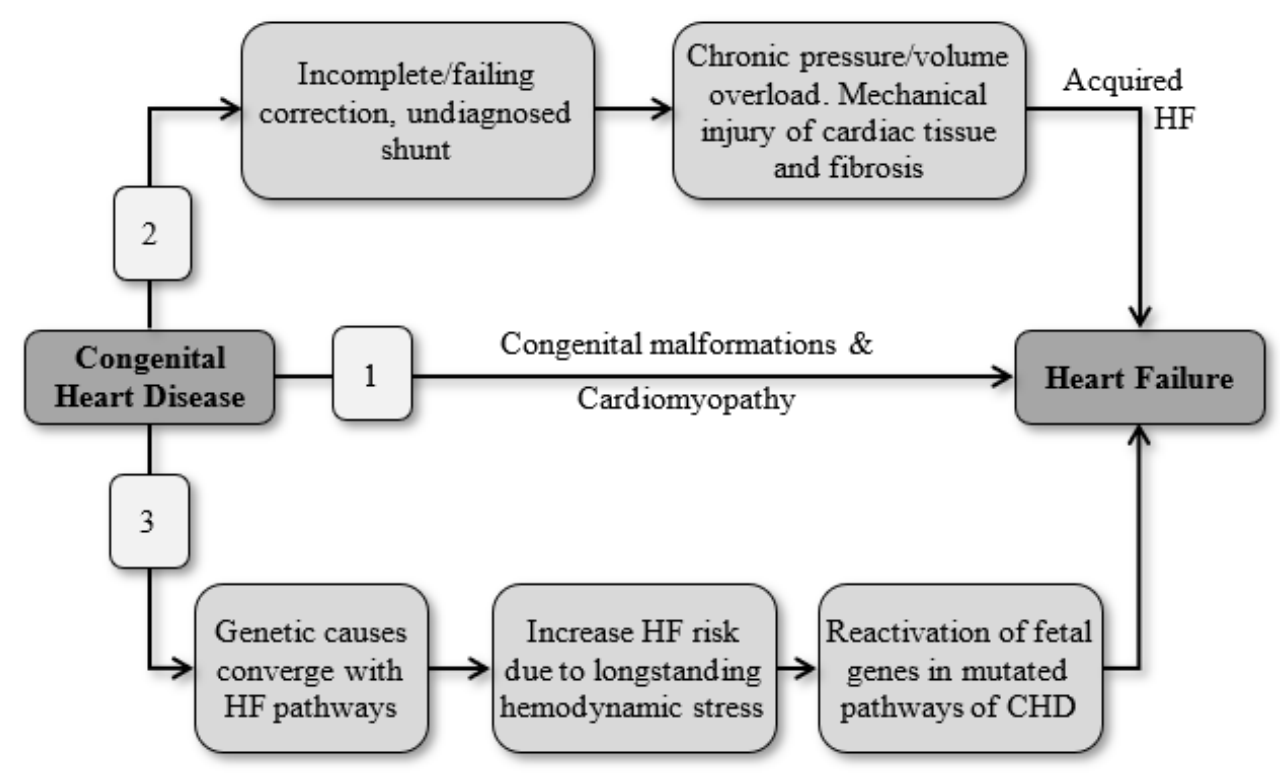

Figure 1. Pathophysiologic mechanisms of the progression of CHD to heart failure

CHD may progress to HF in three major pathways. (1) Genetic etiologies leading to both CHD and HF; (2) Severe CHD lesions in which hemodynamic effects or surgery lead to HF; and (3) A confluence of complex genetics and acquired stressors due to lesions leading to HF [12]

not routinely advised [21,22] but two well-established non-syndromic genes GATA4 and Nkx2-5 in familial CHD are available for clinical genetic testing [20]. There are also several genetically characterized syndromes particularly Noonan, Williams-Beuren and 22.q11.2 deletion syndromes, where CHD and HF are common morbidities [12,20]. Noonan syndrome is a frequent syndromic form of $\mathrm{CHD}$ that can cause both $\mathrm{CHD}$ and cardiomyopathy. Left ventricular non-compaction (LVNC), characterized by an arrest of myocardial morphogenesis, is another common form of congenital cardiomyopathy that often results in HF. It has been associated with acyanotic CHD conditions such as atrial and ventricular septal defects, Ebstein anomaly and outflow tract lesions caused by genes such as MyH7 and transcription factor NKX2 [23-27].

\section{Combined genetic and non-genetic}

Post-hoc analysis of the Dutch Registry including 10,808 CHD patients followed for a median of 21 years reported a high incidence of HF-admission (1.2 per 1,000 patient years), which was ten-fold more than reported in age-matched cohorts without CHD (0.1 per 1,000 patient years) [28]. The findings suggest genetic and non-genetic etiologies of $\mathrm{CHD}$ alone are unlikely to explain the relative high incidence of $\mathrm{HF}$ in $\mathrm{CHD}$, indicating the involvement of additional mechanisms for the progression of CHD to HF. The combination of genetic factors and acquired hemodynamic stressors has been suggested as the another pathway in the progression of CHD to HF because of a significant overlap in the molecular pathways that result in CHD during development and those that are responsible for the integrity of the postnatal myocardium [12]. The overlap suggests molecular perturbations resulting in abnormal cardiac development can increase the likelihood for HF in adulthood, particularly in the presence of long-standing hemodynamic stressors.

At present, limited understanding of the interplay between genetics and hemodynamic stressors in the development of HF in CHD patients is attributable to separate research on genetics of CHD and HF. The few studies based on animal models and in-vitro investigation on directly shared disease genes reveal significant evidence of the involvement of shared molecular pathways [12]. Several genes expressed in embryonic cardiac development are also expressed in the adult heart where they play a role in modulating cardiomyocyte survival and integrity [20]. Two transcription factor genes involved in embryonic cardiac development (GATA4 and GATA6), which are mutated in familial cases of $\mathrm{CHD}$, are also potent activators of cardiac natriuretic peptides (NP) - atrial natriuretic peptide (ANP) and B-type natriuretic peptide (BNP) in the adult heart. The two genes also regulate the transcription of cardiac sarcomere genes alpha and beta-myosin heavy chain [28]. In addition, GATA4 regulates the antiapoptotic gene BCL-X and thus a survival factor for adult cardiomyocyte. Cardiomyocyte apoptosis plays a major role in the pathophysiology of HF and its pharmacological enhancement has a protective effect against cardiomyocyte toxicity and drug-induced cardiotoxicity [29]. Mutations in GATA4 or GATA6 genes increases cardiomyocyte apoptosis predisposing these patients to $\mathrm{HF}$ in the setting of other insults such as $\mathrm{CHD}$-associated volume overload [30].

\section{Predisposing factors}

The key predisposing factors for early development of HF in adult CHD patients are residual substrates after corrective surgery for the underlying cardiac defect and the presence of comorbidities, which may precipitate or aggravate the development of HF [11,14].

\section{Residual substrates:}

Pediatric patients with CHD who survive to adulthood often have one or more residual substrates, which increases the risk of early development of clinical syndrome of HF, which may be right-sided, left-sided or bi-ventricular (involve both sides of the circulation). The ACC/AHA guidelines for adult CHD identified and listed typical substrates in adult CHD patients that increase the risk of subsequent HF development as follows: 
Albakri A (2018) Heart failure in congenital heart disease: A review of clinical status and meta-analysis of diagnostic value of serum natriuretic peptides, and medical and device therapies

a) Severe aortic stenosis (AS) and/or regurgitation bicuspid aortic valves (BAV), sub-valvular or supra-valvular pathology, superimposed coarctation;

b) Severe congenital mitral stenosis or regurgitation;

c) Unoperated atrial septal defect (ASD) or partial atrioventricular septal defect (AVSD);

d) Congenitally corrected TGA;

e) D-transposition after Mustard or Senning operation, where the morphological RV is the systemic ventricle;

f) Tetralogy of Fallot with early-era surgery, long-standing shunt, or severe pulmonary regurgitation;

g) Single Ventricle physiology; and

h) Fontan surgery

In addition to these residual substrates, other possible pathogenic factors for $\mathrm{HF}$ in adult $\mathrm{CHD}$ patients include prolonged cyanosis, prolonged pressure overload, prolonged volume overload, poor myocardial intra-operative preservation, large ventricular septal patch/ incision/scar, residual LV outflow tract (LVOT) or RVOT obstruction, arrhythmias or obesity [14].

\section{Comorbidities}

Knowledge of common comorbidities in CHD patients is important to improve diagnosis and to inform appropriate clinical management strategy. Comorbidities unrelated to adult CHD patients can contribute to or initiate the development of clinical syndrome of HF [14]. Liver disease is often comorbid with adult CHD associated with chronic elevated systemic venous pressures that leads to liver stiffness and cardiac liver cirrhosis or failing Fontan circuit [31-33]. Dual therapy of heart and liver transplantation is usually recommended when failing ventricle co-occurs with liver cirrhosis in CHD patients [34]. Protein loosing enteropathy (PLE) is another common comorbidity found in adult CHD patients, which occurs in the present of failing Fontan circuit and triggered by elevated systemic venous filling pressure [35]. Plastic bronchitis is a rare complication following Fontan palliation, which may require hemodynamic optimization and pulmonary vasodilation therapies to improve clinical course [36]. The presence of elevated central venous pressure and low cardiac output are likely candidates for the formation of tracheobronchial casts [36]. Renal dysfunction is common in about 30 to $50 \%$ of adult CHD patients [37]. The risk of developing chronic kidney disease (CKD) increases significantly in $\mathrm{CHD}$ patients with cyanotic disease but also present in acyanotic diseases. Some hematological disorders can also manifest in adult CHD patients with chronic systemic cyanosis [38] leading to high blood viscosity and low-flow predisposing these patients to thrombosis [39]. Other important comorbid conditions unrelated to adult CHD bur increase HF risk include acquired valvular disease, CAD, systemic hypertension, diabetes mellitus, pregnancy, endocarditis, chronic respiratory disease, cardiotoxic chemotherapy or mediastinal irradiation, illicit drug use, obstructive sleep apnea or hyperthyroidism [14].

\section{Diagnosis}

Definitive diagnosis of HF in CHD patients depends on specific knowledge of the baseline heart defect, and history of surgeries and/ or percutaneous interventions. Determining the underlying etiology is essential because it may be reversible because of a new or worsening residual hemodynamic lesion or a treatable co-morbid condition [40]. However, diagnosis remains a clinical challenge because patients often do not recognize the subtle changes in functional class and that patients might not exhibit typical HF symptoms and signs despite increased exercise intolerance and New York Heart Association (NYHA) functional class I [40]. Moreover, NYHA functional classification is inadequate for cyanotic adult CHD patients with HF, who may present with dyspnea without having HF [14].

\section{Clinical presentation}

$\mathrm{HF}$ in CHD patients follows the classical signs and symptoms of $\mathrm{HF}$ as described in the European Society of Cardiology (ESC) HF Guidelines [41]. Typical symptoms include exercise intolerance, dyspnea and fatigue while symptoms include gallop rhythm, pulmonary crepitations, elevated jugular pressure and hepatomegaly. A comprehensive list is provided in Table 1. Moreover, in some CHD patients with complex CHD, they exhibit worsening cyanosis in the context of intra- or extra-cardiac shunts or fenestrations. In these patients, arrhythmias are closely related to HF symptoms and may represent the first clinical manifestation of the progression of $\mathrm{CHD}$ to HF [41].

\section{Diagnostic methods}

HF in CHD is a clinical syndrome whose diagnosis is made based on patient medical history, examination and investigations. Diagnostic work-up usually involves a range a tests including laboratory testing,

Table 1. Signs and symptoms of HF in adult CHD patients. (Adapted from the 2012 ESC HF Guidelines [41] )

\begin{tabular}{|c|c|c|}
\hline Description & Symptoms & Signs \\
\hline \multirow{7}{*}{ Systemic ventricular failure } & Fatigue & 3rd or 4th heart sound (gallop rhythm) \\
\hline & Breathlessness & Laterally displaced apical impulse \\
\hline & Cry cough when lying flat & Pulmonary crepitations \\
\hline & Exercise intolerance & $\begin{array}{l}\text { Absent breath sound, dull percussion lung bases due to pleural } \\
\text { effusion }\end{array}$ \\
\hline & Orthopnea & \\
\hline & Paroxysmal nocturnal dyspnea & \\
\hline & Wheezing & \\
\hline \multirow{6}{*}{ Sub-pulmonary ventricular failure } & Fatigue & Elevated jugular venous pressure \\
\hline & Bloating & Hepatomegaly \\
\hline & Weight gain $(>2 \mathrm{~kg} /$ week) & Ascites \\
\hline & Loss of appetite & Pitting leg edema, sacral edema or scrotal edema \\
\hline & Exercise intolerance & \\
\hline & Increased abdominal girth & \\
\hline Congestive (bi-ventricular) failure & Combined systemic and sub-pulmonary symptoms & Combined systemic and sub-pulmonary signs \\
\hline
\end{tabular}



and device therapies

electrocardiograph (ECG), imaging tests (mainly echocardiography [echo], magnetic resonance imaging [MRI], computed tomography $[\mathrm{CT}]$ and cardiac catheterization) and cardiopulmonary exercise testing [42].

\section{Laboratory testing}

The ESC treatment guidelines recommend all adult CHD patients suspected with HF should undergo basic laboratory tests including blood tests, renal function, liver function, iron, protein and albumin, and thyroid function. Laboratory tests are essential to identify an underlying treatable conditions especially anemia, renal/liver impairment, hypoalbuminemia, hyponatremia, and iron depletion [42]. In blood tests, a more clinically significant test is the evaluation of the levels of serum NPs to assess cardiac function because neurohormonal activation is one of the triad of HF in CHD. Others are cardiac abnormality and exercise limitation [43]. Serum levels of BNP and N-terminal pro-BNP (NT-proBNP) correlate with disease severity and prognosis in HF patients with both acquired and congenital heart diseases $[44,45]$ and in individual cardiac malformations in adult CHD patients. In adult CHD patients with unrepaired and repaired atrial septal defect or ventricular septal defect (VSD), BNP levels are mildly increased [45], correlate strongly with shunt severity, pulmonary artery pressure (PAP) and functional class [46,47]. In patients with Tetralogy of Fallot, serum BNP levels correlate with RV dilation, severity of pulmonary valve regurgitation and exercise capacity [48-50]. In systemic morphological RV dysfunction, there is correlation between BNP and RV function [45], and the severity of tricuspid regurgitation (TR), and between ANP with ejection fraction [51,52]. In symptomatic hypoxia and single defect conditions, BNP levels correlate with HF severity [53] but no correlation between BPs and oxygen saturation [54-56].

\section{Electrocardiography}

Adult CHD patients exhibit abnormal ECG at presentation/ baseline. Common ECG abnormalities include prolonged QRS duration, intra-ventricular conduction delay, nodal rhythm and LV or RV hypertrophy. Although ECG abnormalities are relevant in adult CHD patients, the findings should be interpreted after atrioventricular conduction abnormalities (total AV block in CCTGA) or for in appropriate sinus tachycardia that mimics atypical supraventricular reentrant tachycardia [42].

\section{Imaging tests}

Different imaging tests reveal different signs of cardiac malformations to support the diagnosis of HF in CHD. Chest X-ray is recommended to evaluate the position and size of the heart, size of pulmonary arteries, thoracic aorta, and co-occurring lung and thorax pathology. The test identifies pulmonary congestion and effusion [42]. Echo allows for the diagnosis of underlying CHD, detect concomitant/ residual lesions and sequelae, assess sub aortic/pulmonary function, detect new lesions and monitor disease progression [57]. Threedimensional echo is more sensitive than two-dimension in evaluating ventricular function, valves and volumes, stress echo may be considered in assessing contractile reserve and diagnosis of acquired diseases such as $\mathrm{CAD}[58,59]$.

Cardiac MRI is currently the gold standard for volumetric measurements, ventricular function, anatomical connection, and detection of myocardial fibrosis [42]. The 2010 ESC guidelines for MRI in CHD patients recommends its use: (a) when echo findings are suboptimal and unable to provide images and measurement of adequate quality to inform clinical management. (b) When echo measurement are borderline or ambiguous. (c) When MRI informs management more effectively - evaluating systemic/pulmonary veins, RVOT, RVPA conduits; quantification of RV volumes and ejection fraction, pulmonary regurgitation, shunts by measurement of flow in aorta and pulmonary trunk and myocardial fibrosis and mass, and tissue characterization [60].

Other imaging tests that may routinely indicated include computed tomography (CT) and cardiac catheterization. CT is indicated for visualizing (a) stented vales and coarctation stents along with the epicardial coronary arteries; (b) collateral arteries; and (c) parenchymal lung disease [61]. Cardiac catheterization provides information on hemodynamics for circulating pulmonary vascular resistance, and assessment of LV/RV diastolic function, pressure gradients and shunt quantification [62].

\section{Cardiopulmonary exercise test}

Cardiopulmonary exercise test (CPET) is a valuable diagnostic tool with prognostic implications. Adult CHD patients exhibit exercise intolerance. The expected peak oxygen consumption varies across the different types of CHD [63]. There is a good correlation between CPET and mortality, which shows an increasing trend towards CHD patients with peak oxygen consumption $\left(\mathrm{VO}_{2}\right)<15 \mathrm{~mL} / \mathrm{min} / \mathrm{kg}$ [64]. Lung function test can be indicated to assess for comorbid bronchopulmonary disease [42].

\section{Meta-analysis of diagnostic value of NPs HF in CHD}

In CHD patients, HF mainly results from accumulating cardiac pressure, volume, tension and flow, which clinically manifests as a triad of neurohormonal activation, cardiac dysfunction and reduced exercise tolerance. Serum NPs (mainly BNP and NT-proBNP) are important cardiac biomarkers released into circulation after pressure and volume overload, and increased myocardial wall stress. The active fragments of these markers possess natriuretic, vasodilatory and diuretic effects $[44,45]$. Although changes in serum concentration of NPs are very useful in detecting cardiac impairment in the general population, their role in the diagnosis of CHD patients is not well defined. In this metaanalysis, we evaluate published evidence on diagnostic value of serum NPs in patients with CHD and clarify the relationship between them and hemodynamic changes evaluated using non-invasive imaging.

\section{Study search and selection}

We conducted a systematic published peer-reviewed literature search on PubMed and EMBASE for studies investigating the use of serum NPs and cardiac imaging in the diagnosis of HF in CHD patients. The search terms consisted of CHD (septal defects - atrial septal defect, atrioventricular septal defect, ventricular septal defect, aortic coarctation, pulmonary valve stenosis, tetralogy of Fallot [TOF], transposition of the great arteries/vessels [TGA] and Fontan) AND "brain natriuretic peptide" OR "B-type natriuretic peptide" OR "pro-brain natriuretic peptide". Inclusion criteria were studies that (a) recruited patients with CHD (septal defects, systemic RV or tetralogy of Fallot) often associated with HF; (b) reported serum NPs levels; and (c) reported correlation between serum NPs and ventricular functional parameters assessed by imaging tests. Studies including both adults and children were included. There was no restriction on publication language and year. Animal studies, case series/reports and conference papers were excluded. Additional studies were searched from references of included studies and review articles, and crosschecked with the inclusion criteria for eligibility. 
Albakri A (2018) Heart failure in congenital heart disease: A review of clinical status and meta-analysis of diagnostic value of serum natriuretic peptides, and medical and device therapies

We extracted data on study characteristic (author and year), patient characteristics (number and mean age), baseline characteristics (type of CHD, serum NPs levels) and correlation $(r)$ between serum NPs levels and cardiac functional parameters assessed using imaging (echo, MRI or cardiac catheterization). For all qualifying studies, inclusion was assessed by two reviewers and any discrepancy resolved though consensus. In analysis, we expressed categorical data as frequency or percentage and continuous data as mean and standard deviation. We calculated weighted summary correlation coefficient between serum NPs and cardiac function parameters under the fixed effect model using a Fisher $\mathrm{Z}$ transformation of the correlation coefficient. For a high heterogeneity across studies, we calculated $\mathrm{I}^{2}$ statistics and incorporated the summary correlation coefficient under the random effects model.

\section{Study characteristics and outcomes}

The literature search yielded 201 studies. Initial title and abstract screening excluded 152 studies investigating unrelated topic from this meta-analysis. Additional 18 studies were excluded because they did not report on data on serum NPs and/or correlation with cardiac function parameters. The remaining 31 articles satisfied the inclusion criteria and were included in this meta-analysis [47,48,66-93]. In all, the 31 studies included CHD patients ranging from pediatrics to adults $(\mathrm{n}=1,185$; mean age $15.9 \pm 11.9)$. The main CHD sub-population investigated were patients with simple cardiac defect (ASD, VSD and PDA) $(\mathrm{n}=12)[47,65-75]$ and with complex cardiac defect (systemic RV and Tetralogy of Fallot [ToF]) $(\mathrm{n}=19)[48,76-93]$. Seventeen studies [65$68,70-72,74,75,77-79,81,84,86,90,91]$ investigated BNP and reported a weighted mean of $32.5 \pm 12.38 \mathrm{pg} / \mathrm{ml}$, while the remaining 14 studies $[47,48,69,73,76,80,82,83,85,87-89,92,93]$ investigated NT-proBNP reporting a weighted mean of $175.48 \pm 57.77 \mathrm{pg} / \mathrm{ml}$.

Weighted summary correlation between concentration of serum BNPs or NT-proBNPs and cardiac function parameters assessed by echo, cardiac MRI or cardiac catheterization using a Fisher Z transformation of correlation coefficient demonstrate mixed findings (Table 2). Using fixed effect model, correlation coefficient from 18 studies [76-93] including 592 patients showed BNP or NT-proBNP had a strong negative correlation with RV ejection fraction $(r-0.45 ; 95 \% \mathrm{CI}$ : -0.53 to -0.35$)$ and a positive correlation with RVEDV ( $r=0.52 ; 95 \% \mathrm{CI}$ : 0.44 to 0.58$)$ in 16 studies $(\mathrm{n}=593)[47,48,65,74,77,80,82,83,85,85,87$ $89,91,92,93]$. In eight $[78,79,81,86,88,90,92,93]$ and four $[85,89,92,93]$ studies, the correlation was insignificant between BNP/NT-proBNP, and RVEF and RVEDV respectively, but nonetheless, suggested a trend towards higher concentration of serum NPs and increasing cardiac dysfunction. In nine studies [47,65-67,70,71,72,74,75] with 440 patients, BNP/NT-proBNP had a significant correlation with Qp/ Qs $(r=0.65 ; 95 \%$ CI: 0.53 to 0.75$)$. Other cardiac parameters correlating with BNP/NT-proBNP were RVEDD ( $r=0.44 ; 95 \%$ CI: 0.23 to 0.61$)$; RVESV ( $r=0.56$; 95\% CI: 0.33 to 0.72 ); LVEDD ( $r=0.49$; 95\% CI: 0.22 to 0.70 ) and LVESV ( $r=0.48 ; 95 \% \mathrm{CI}: 0.21$ to 0.68 ). However, there was no significant correlation between BNPs/NT-proBNPs with LVEDV ( $r$ $=0.38 ; 95 \%$ CI: -0.27 to $0.80 ; \mathrm{p}=0.25)$. Two studies $[67,74]$ compared BNP levels between CHD patients and age-matched healthy controls and reported that CHD patients had significantly higher BNP levels $(60.6 \pm 49.9$ vs. $32.6 \pm 24.5 \mathrm{pg} / \mathrm{ml}, \mathrm{p}=0.02)$ [67] and ( $42.9 \pm 29.4$ vs. $8.3 \pm 2.6 \mathrm{pg} / \mathrm{mL}, \mathrm{p}<0.05)$ [74]. In all, the findings indicate a significant correlation between serum concentrations of BNP/NT-proBNP and cardiac imaging (echocardiographic, MRI and cardiac catheterization) parameters of patients with CHD.

\section{Discussion of findings}

This systematic review and meta-analysis demonstrates that serum NPs - BNPs and NT-proBNPs - represent potential clinical markers for cardiac function and hemodynamics in CHD patients. The concentration of serum BNPs and NT-proBNPs was elevated in patients with simple cardiac defect or complex CHD. The values were higher when compared to age-matched controls. There was a strong and positive correlation between BNPs or NT-proBNPs with the ratio of pulmonary to systemic blood flow $(\mathrm{Qp} / \mathrm{Qs})$ in all patients with simple cardiac defect (ASD, PDA and VSD). In other cardiac function parameters (RVEF, RVEDV, RVEDD, RVESV, LVEDD, or LVESV), a strong correlation existed between serum levels of BNP or NT-proBNPs with cardiac function parameters. However, some studies reported a non-significant relationship. Moreover, in LVEDV, there was no significant relationship with serum NPs in patients with PDA, VSD and $\mathrm{CoA}$. The mixed findings suggest a wide range of BNPs or NT-proBNPs values and thus, caution should be observed when drawing conclusions for individual CHD patients.

The present findings are supported from two earlier systematic review articles investigating the relationship between BNPs or NTproBNPs with cardiac function, structure and hemodynamics on CHD patients with simple cardiac (septal) defect [43] and those with complex cardiac defect - systemic RV, ToF and univentricular hearts [94]. The two systematic review reported elevated serum NPs levels in CHD patients except in asymptomatic patients where levels were comparable to sex- and age-matched controls. Despite a positive correlation between the levels of serum NPs and cardiac function parameters, a position paper on adult CHD by the Working Group of Grown-up CHD and HF Association of the ESC suggest limited clinical value in the diagnosis of HF in CHD [42]. The serum levels of NPs can vary widely due to heterogeneity of underlying causes and clinical presentation. Many studies have not incorporated these factors complicating the diagnostic value of BNPs or NT-proBNPs in CHD patients with HF [42]. Serum levels of NPs also correlate with comorbidities, age and sex, which makes the need for individual consideration valid.

Although the suggested correlation between serum NPs and cardiac function parameters could have important clinical

Table 2. Weighted summary correlation between serum NPs and cardiac function

\begin{tabular}{|c|c|c|c|c|}
\hline $\begin{array}{l}\text { Cardiac Function Parameters assessed by echo, cardiac MRI or cardiac } \\
\text { catheterization }\end{array}$ & $\begin{array}{l}\text { Weighted Summary } \\
\text { Correlation (r) }\end{array}$ & $95 \%$ CI & $\begin{array}{l}\text { No. of studies } \\
\text { providing data }\end{array}$ & $\begin{array}{l}\text { No. of included } \\
\text { patients }\end{array}$ \\
\hline RVEF [76-93] & -0.4 & -0.53 to -0.35 & 18 & 592 \\
\hline RVEDV $[47,48,65,74,77,80,82-85,87-89,91-93]$ & 0.52 & 0.44 to 0.58 & 16 & 593 \\
\hline RVEDD $[67,68,73,78,79]$ & 0.44 & 0.23 to 0.61 & 5 & 147 \\
\hline RVESV $[80,82]$ & 0.56 & 0.33 to 0.72 & 2 & 54 \\
\hline LVEDV $[65,73]$ & 0.38 & -0.27 to 0.80 & 2 & 160 \\
\hline LVEDD $[68,73]$ & 0.49 & 0.22 to 0.70 & 2 & 43 \\
\hline LVESV [69.73] & 0.48 & 0,21 to 0.68 & 2 & 43 \\
\hline Qp/Qs $[47,65-67,70,71,72,74,75]$ & 0.65 & 0.53 to 0.75 & 9 & 440 \\
\hline
\end{tabular}


Albakri A (2018) Heart failure in congenital heart disease: A review of clinical status and meta-analysis of diagnostic value of serum natriuretic peptides, and medical and device therapies

implications, several demonstrated challenges undermine their clinical utility. First, clinical demonstrated HF in CHD patients remains a rare condition with a general lack of appropriate largescale clinical trials demonstrating the relationship between serum NPs levels and cardiac function in these patients. As such, most of the studies included in the present meta-analysis adopted a cross-sectional design, included both asymptomatic and symptomatic HF patients and the assessment of serum NPs levels with cardiac function was not the original objective. The inclusion of asymptomatic and mildly symptomatic patients (NYHA I and II), and thus, true values of serum NPs concentration in CHD patients with clinically demonstrated HF remain largely uncertain. Nevertheless, in patients with ToF, where all functional classes were investigated, there were strong association between serum NPs levels and functional class.

In all, serum levels of NPs have been used in assessing cardiac dysfunction in HF patients in the general population. However, in CHD patients with HF, the diagnostic value of serum NPs levels remain challenging. Heterogeneity in causes, and in clinical signs and symptoms as well as variation in sex, age and comorbidities affect serum NPs levels. Larger clinical trials specific to CHD patients with HF would provide the evidence for the diagnostic value of HF in different subpopulation of CHD patients. Such findings would improve diagnosis and clinical management of $\mathrm{HF}$ in $\mathrm{CHD}$ patients while acknowledging variation in individual patients.

\section{Clinical management}

Clinical management of HF in CHD patients remains a clinical challenge because of the lack of specific evidence-based and guidelinedirected therapies. Clinical trials with hard clinical endpoints (death, recurrence or rehospitalization for adverse cardiac events) in adult CHD patients are lacking. Although the events inciting HF in adult CHD patients differ from those in other forms of HF, consensus guidelines for treatment of HF [95] are often used for adult CHD patients because of the lack of adequate controlled data in this sub-population $[14,42]$. Common treatment strategies include medical therapy, device therapy, cardiopulmonary and physical rehabilitation, and heart transplantation [42].

\section{Medical therapy}

Consensus guidelines for medical treatment for HF has been used in CHD patients. Indication for medication therapy targets treating systolic failure based on the underlying morphological cause such as systemic ventricular failure, sub-pulmonary ventricular failure, single ventricular failure and HF with preserved ejection fraction (Table 3). The aim of medical therapy should serve to achieve one of two purposes: to improve prognosis or to alleviate symptoms [95].

In adult CHD patients with systemic LV failure, the ESC guidelines recommend diuretics, RAAs blockers, beta-blockers and MRAs particularly in the presence of increased neurohormonal and cardiac

Table 3. Summary of included studies on diagnostic value of serum NPs in HF in CHD

\begin{tabular}{|c|c|c|c|c|c|c|c|c|c|c|c|c|c|c|c|}
\hline 1st Author & Year & $\begin{array}{l}\text { No. of } \\
\text { Patients }\end{array}$ & $\begin{array}{l}\text { Age } \\
\text { (years) }\end{array}$ & CHD & \begin{tabular}{|l} 
Function \\
Assessment
\end{tabular} & BNP & $\begin{array}{l}\text { NT- } \\
\text { proBNP }\end{array}$ & $\begin{array}{l}\text { RVEF } \\
\text { (r) }\end{array}$ & $\begin{array}{l}\text { RVEDV } \\
\text { (r) }\end{array}$ & $\begin{array}{l}\text { RVEDD } \\
\text { (r) }\end{array}$ & $\begin{array}{l}\text { RVESV } \\
\text { (r) }\end{array}$ & $\begin{array}{l}\text { LVEDV } \\
\text { (r) }\end{array}$ & $\begin{array}{l}\text { LVEDD } \\
\text { (r) }\end{array}$ & $\begin{array}{l}\text { LVESV } \\
\text { (r) }\end{array}$ & Qp/Qs (r) \\
\hline \multirow{3}{*}{$\begin{array}{l}\text { Kunii et al. } \\
{[65]}\end{array}$} & \multirow{3}{*}{2003} & 34 & 5.8 & ASD & $\mathrm{CC} /$ Echo & $37.6 \pm 8.4$ & & & $\begin{array}{l}0.81 \\
\mathrm{p}<0.001\end{array}$ & & & & & & $\begin{array}{l}0.69 \\
p<0.001\end{array}$ \\
\hline & & 29 & 3.1 & PDA & $\mathrm{CC} /$ Echo & $32.8 \pm 6.5$ & & & & & & $\begin{array}{l}0.79 \\
\mathrm{p}<0.0001\end{array}$ & & & $\begin{array}{l}0.89 \\
\mathrm{p}<0.0001\end{array}$ \\
\hline & & 91 & 3.4 & VSD & $\mathrm{CC} /$ Echo & $46.1 \pm 7.3$ & & & & & & $\begin{array}{l}0.72 \\
\mathrm{p}<0.0001\end{array}$ & & & $\begin{array}{l}0.75 \\
\mathrm{p}<0.0001\end{array}$ \\
\hline $\begin{array}{l}\text { Suda et al. } \\
{[66]}\end{array}$ & 2003 & 59 & 3.1 & VSD & $\mathrm{CC}$ & $25 \pm 20$ & & & & & & & & & $\begin{array}{l}0.65 \\
\mathrm{p}<0.0001\end{array}$ \\
\hline $\begin{array}{l}\text { Trojnarska et } \\
\text { al. [67] }\end{array}$ & 2006 & 36 & 44.7 & ASD & Echo & $60.6 \pm 49.9$ & & & & $\begin{array}{l}0.38 \\
\mathrm{p}<0.03\end{array}$ & & & & & $\begin{array}{l}0.39 \\
\mathrm{p}<0.03\end{array}$ \\
\hline $\begin{array}{l}\text { Chen et al. } \\
{[68]}\end{array}$ & 2007 & 18 & 12.4 & VSD & Echo & $20.8 \pm 6.1$ & & & & $\begin{array}{l}0.59 \\
\mathrm{p}=0.01\end{array}$ & & & $\begin{array}{l}0.56 \\
\mathrm{p}=0.02\end{array}$ & & \\
\hline $\begin{array}{l}\text { Eerola et al. } \\
\text { [69] }\end{array}$ & 2007 & 24 & 6.9 & ASD & $\mathrm{CC} /$ Echo & & $85(11-245)$ & & & & & & & $\begin{array}{l}0.47 \\
\mathrm{p}<0.02\end{array}$ & \\
\hline $\begin{array}{l}\text { Mainwaring } \\
\text { et al. [70] }\end{array}$ & 2007 & 18 & $2-15.6$ & VSD & $\mathrm{CC}$ & $60(15-175)$ & & & & & & & & & $\begin{array}{l}0.85 \\
\mathrm{p}<0.001\end{array}$ \\
\hline $\begin{array}{l}\text { Schoen et al. } \\
{[47]}\end{array}$ & 2007 & 20 & 43.0 & ASD & MRI/Echo & & $240 \pm 93$ & & $\begin{array}{l}0.65 \\
\mathrm{p}<0.05\end{array}$ & & & & & & $\begin{array}{l}0.63 \\
\mathrm{p}<0.05\end{array}$ \\
\hline $\begin{array}{l}\text { Oyamada et } \\
\text { al. [71] }\end{array}$ & 2008 & 48 & 0.8 & VSD & CC/Echo & $33.7 \pm 16.5$ & & & & & & & & & $\begin{array}{l}0.41 \\
\mathrm{p}=0.004\end{array}$ \\
\hline \begin{tabular}{|l} 
Toyono et al. \\
{$[72]$}
\end{tabular} & 2008 & 24 & 0.3 & VSD & $\mathrm{CC}$ & $31 \pm 18.9$ & & & & & & & & & $\begin{array}{l}0.59 \\
\mathrm{p}=0.003\end{array}$ \\
\hline \multirow{3}{*}{$\begin{array}{l}\text { Eerola et al. } \\
\text { [73] }\end{array}$} & \multirow{3}{*}{2009} & 21 & 5.2 & ASD & Echo & & $79(11-245)$ & & & $\begin{array}{l}0.41 \\
\mathrm{p}<0.01\end{array}$ & & & & $\begin{array}{l}0.49 \\
\mathrm{p}<0.025\end{array}$ & \\
\hline & & 25 & 2.6 & PDA & Echo & & $\begin{array}{l}\text { 141(36- } \\
974(\end{array}$ & & & & & $\begin{array}{l}0.41 \\
\mathrm{p}<0.042\end{array}$ & $\begin{array}{l}0.446 \\
\mathrm{p}<0.025\end{array}$ & & \\
\hline & & 15 & 2.0 & $\mathrm{CoA}$ & Echo & & $\begin{array}{l}128(5- \\
35001)\end{array}$ & & & & & $\begin{array}{l}-0.74 \\
\mathrm{p}<0.001\end{array}$ & & & \\
\hline Uz et al. [74] & 2011 & 56 & 22.9 & ASD & Echo & $42.9 \pm 29.4$ & & & $\begin{array}{l}0.55 \\
\mathrm{p}<0.0001\end{array}$ & & & & & & $\begin{array}{l}0.71 \\
\mathrm{p}<0.001\end{array}$ \\
\hline Jan et al. [75] & 2012 & 25 & 4.6 & ASD & $\mathrm{CC} /$ Echo & $11.4 \pm 13.5$ & & & & & & & & & $\begin{array}{l}0.183 \\
\mathrm{p}<0.166\end{array}$ \\
\hline $\begin{array}{l}\text { Dore et al } \\
{[76]}\end{array}$ & 2005 & 29 & 30.9 & SRV & Echo & & $258 \pm 243$ & $\begin{array}{l}-0.42 \\
p=0.02\end{array}$ & & & & & & & \\
\hline $\begin{array}{l}\text { Chow et al. } \\
{[77]}\end{array}$ & 2008 & 44 & 19.7 & SRV & Echo & $19(6-522)$ & & $\begin{array}{l}-0.43 \\
\mathrm{p}=0.001\end{array}$ & $\begin{array}{l}0.37 \\
p=0.009\end{array}$ & & & & & & \\
\hline
\end{tabular}


Albakri A (2018) Heart failure in congenital heart disease: A review of clinical status and meta-analysis of diagnostic value of serum natriuretic peptides, and medical and device therapies

\begin{tabular}{|c|c|c|c|c|c|c|c|c|c|c|c|c|c|c|c|}
\hline 1st Author & Year & $\begin{array}{l}\text { No. of } \\
\text { Patients }\end{array}$ & $\begin{array}{l}\text { Age } \\
\text { (years) }\end{array}$ & CHD & $\begin{array}{l}\text { Function } \\
\text { Assessment }\end{array}$ & BNP & $\begin{array}{l}\text { NT- } \\
\text { proBNP }\end{array}$ & $\begin{array}{l}\text { RVEF } \\
\text { (r) }\end{array}$ & $\begin{array}{l}\text { RVEDV } \\
\text { (r) }\end{array}$ & $\begin{array}{l}\text { RVEDD } \\
(\mathbf{r})\end{array}$ & $\begin{array}{l}\text { RVESV } \\
\text { (r) }\end{array}$ & $\begin{array}{l}\text { LVEDV } \\
\text { (r) }\end{array}$ & $\begin{array}{l}\text { LVEDD } \\
\text { (r) }\end{array}$ & $\begin{array}{l}\text { LVESV } \\
\text { (r) }\end{array}$ & Qp/Qs (r) \\
\hline $\begin{array}{l}\text { Garg et al. } \\
{[78]}\end{array}$ & 2008 & 24 & 24.0 & SRV & MRI & $15.4 \pm 18.2$ & & NS & & NS & & & & & \\
\hline $\begin{array}{l}\text { Koch et al. } \\
{[79]}\end{array}$ & 2008 & 48 & 19.0 & SRV & Echo & $20(5-198)$ & & NS & & NS & & & & & \\
\hline $\begin{array}{l}\text { Kozelj et al. } \\
{[80]}\end{array}$ & 2008 & 19 & 35.0 & SRV & $\begin{array}{l}\text { Echo/MRI/ } \\
\text { CT }\end{array}$ & & $654 \pm 1535$ & $\begin{array}{l}-0.53 \\
p=0.02\end{array}$ & $\begin{array}{l}0.50 \\
\mathrm{p}=0.026\end{array}$ & & $\begin{array}{l}0.61 \\
\mathrm{p}=0.006\end{array}$ & & & & \\
\hline $\begin{array}{l}\text { Vogt et al. } \\
{[81]}\end{array}$ & 2009 & 16 & 25.6 & SRV & Echo & $67.3 \pm 47.5$ & & NS & & & & & & & \\
\hline $\begin{array}{l}\text { Plymen et al. } \\
\text { [82] }\end{array}$ & 2010 & 35 & 29.0 & SRV & MRI & & $322 \pm 288$ & $\begin{array}{l}-0.54 \\
p<0.001\end{array}$ & $\begin{array}{l}0.43 \\
p=0.01\end{array}$ & & $\begin{array}{l}0.53 \\
\mathrm{p}=0.001\end{array}$ & & & & \\
\hline $\begin{array}{l}\text { Schaefer et } \\
\text { al. [83] }\end{array}$ & 2010 & 43 & 29.0 & SRV & Echo/MRI & & $200 \pm 148$ & $\begin{array}{l}-0.46 \\
\mathrm{p}=0.002\end{array}$ & $\begin{array}{l}0.32 \\
\mathrm{p}-0.044\end{array}$ & & & & & & \\
\hline $\begin{array}{l}\text { Ishii et al. } \\
\text { [84] }\end{array}$ & 2005 & 26 & 9.6 & ToF & Echo & $44 \pm 34$ & & $\begin{array}{l}-0.42 \\
p=0.03\end{array}$ & & & & & & & \\
\hline $\begin{array}{l}\text { Norozi et al } \\
{[48]}\end{array}$ & 2005 & 50 & 27.8 & ToF & Echo & & $166 \pm 25$ & & $\begin{array}{l}0.45 \\
\mathrm{p}<0.05\end{array}$ & & & & & & \\
\hline $\begin{array}{l}\text { Dodge- } \\
\text { Khatami et } \\
\text { al. [85] }\end{array}$ & 2006 & 23 & 14.1 & ToF & MRI & & $231 \pm 228$ & $\begin{array}{l}-0.47 \\
p<0.05\end{array}$ & NS & & & & & & \\
\hline $\begin{array}{l}\text { Cheung et al. } \\
\text { [86] }\end{array}$ & 2007 & 32 & 14.7 & ToF & MRI & $\begin{array}{l}21.9(7.8- \\
470)\end{array}$ & & NS & $\begin{array}{l}0.6 \\
p=0.0001\end{array}$ & & & & & & \\
\hline $\begin{array}{l}\text { Festa et al. } \\
{[87]}\end{array}$ & 2007 & 70 & 21.0 & ToF & MRI/Echo & & $218 \pm 30$ & $\begin{array}{l}-0.32 \\
p<0.01\end{array}$ & $\begin{array}{l}0.40 \\
p<0.001\end{array}$ & & & & & & \\
\hline $\begin{array}{l}\text { Khositseth et } \\
\text { al. [88] }\end{array}$ & 2007 & 21 & 12.1 & ToF & MRI/Echo & & $195 \pm 303$ & NS & $\begin{array}{l}0.57 \\
\mathrm{p}=0.01\end{array}$ & & & & & & \\
\hline $\begin{array}{l}\text { Wand et al. } \\
\text { [89] }\end{array}$ & 2007 & 21 & 11.6 & ToF & Echo & & 202 & $\begin{array}{l}-0.50 \\
\mathrm{p}=0.02\end{array}$ & NS & & & & & & \\
\hline $\begin{array}{l}\text { Apitz et al. } \\
{[90]}\end{array}$ & 2009 & 16 & 14.2 & ToF & MRI & $19(7-42)$ & & NS & & & & & & & \\
\hline $\begin{array}{l}\text { Çetin et al. } \\
{[91]}\end{array}$ & 2009 & 25 & 14.1 & ToF & Echo & $28.3 \pm 24.1$ & & $\begin{array}{l}-0.60 \\
p=0.0001\end{array}$ & $\begin{array}{l}0.7 \\
p=0.0001\end{array}$ & & & & & & \\
\hline $\begin{array}{l}\text { Van den Berg } \\
\text { et al. [92] }\end{array}$ & 2009 & 51 & 15.0 & ToF & MRI & & $85(17-355)$ & NS & NS & & & & & & \\
\hline $\begin{array}{l}\text { Tatani et al. } \\
\text { [93] }\end{array}$ & 2010 & 49 & 14.7 & ToF & Echo & & $211 \pm 219$ & NS & NS & & & & & & \\
\hline
\end{tabular}

(ASD: Atrial Septal Defects; BNP: B-type Natriuretic Peptide; CoA: Coarctation of the Aorta; Echo: Echocardiograph; LVEDD: Left Ventricular End-Diastolic Diameter; LVEDV: Left Ventricular End-Diastolic Volume; LVESV: Left Ventricular End Systolic Volume; MRI: Magnetic Resonance Imaging; PDA: Patent Ductus Arteriosus; Qp/Qs: Left-to-Right Shunt; r: Correlation Coefficient; RAV: Right Atrial Volumes; RVEDD: Right Ventricular End-Diastolic Diameter; RVEDV: Right Ventricular End-Diastolic Volume; RVEF: Right Ventricular Ejection Fraction; RVESV: Right Ventricular End-Systolic Volume; ToF: Tetralogy of Fallot; VSD: Ventricular Septal Defects)

autonomic activities [95]. Theoretical evidence support the use of angiotensin converting enzyme inhibitor (ACEI) and, if intolerant, angiotensin receptor blockers (ARBs) in treating asymptomatic/ symptomatic HF in adult CHD patients. Data on the use of betablockers such as carvedilol, metoprolol, bisoprolol, and nebivolol in HF patients may be extrapolated to HF in CHD patients with aortic or mitral valve disease [96-98]. Although loop diuretic do not improve survival in chronic HF patients, they alleviate symptoms [42]. In adult CHD patients with systemic RV failure, asymptomatic and without signs of HF, there is no evidence supporting medical therapy would achieve better clinical outcome. In symptomatic patients with neurohormonal activation and cardiac autonomous nervous system activation, standard HF treatment offer theoretical benefit and thus recommended as in patients with LV failure. In CHD patients with sub-pulmonary ventricular failure, diuretics, MRA and pulmonary vasodilators improve prognosis and alleviate symptoms. In adult CHD patients with HF with preserved ejection fraction, diuretics, betablocker, and channel blocker can have better clinical outcomes $[42,65]$.

\section{Exercise training}

Increased exercise intolerance is a common symptom in HF patients and thus exercise training (or cardiopulmonary rehabilitation) has been recommended as both a safe and clinically beneficial intervention in chronic HF patients $[41,99,100]$. Although there is a lack of studies focused on CHD patients with HF, exercise training and cardiac rehabilitation programs has been shown to be safe and effectiveness in improving exercise-related and hemodynamic variables [101-103], improved quality of life in patients with complex CHD [104]. More studies specific to HF in adult CHD are warranted to determine the value of exercise training on improving outcomes in this patients.

\section{Device therapy}

Device therapy is indicated for the prevention of sudden cardiac death (SCD) in HF in CHD. A sub-population of adult CHD patients are at a greater risk of SCD such as patients after surgical repair of tetralogy of Fallot, d-TGA with Mustard/Senning repairs, CCTGA, Eisenmenger syndrome, and Ebstein anomaly of the tricuspid valve [105]. In adult CHD, there is consensus on the use of implantable cardioverter defibrillator (ICD) for secondary prevention of SCD [106]. It is indicated for survivors of SCD secondary to ventricular fibrillation or unstable tachycardia without reversible cause, patients with spontaneous sustained VT non-responsive to ablation or surgery and idiopathic syncope with inducible stable ventricular tachycardia or spontaneous sustained ventricular tachycardia [42]. Selection of ICD candidates for primary prevention of SCD remains a challenge. It is indicated in CHD patients with biventricular physiology with systemic LVEF $<35 \%$ and NYHA class II or III $[107,108]$. Based on risk scores, prophylactic ICD should be considered in selected adults 
Albakri A (2018) Heart failure in congenital heart disease: A review of clinical status and meta-analysis of diagnostic value of serum natriuretic peptides, and medical and device therapies

after surgical repair of tetralogy of Fallot who are at an increased risk for SCD [42].

Cardiac resynchronization therapy (CRT) is a device therapy to correct LV electromechanical dyssynchrony through inducing LV reverse modelling, improving LV function and reducing HF-associated morbidity and mortality $[109,110]$. However, in adult CHD patients, structural heterogeneity of the underlying heart defects complicates the role of CRT. Current evidence is based on short-term studies (4 to 8 months) and thus long-term impact of CTR on morbidity and mortality is not known. Nevertheless, CRT is recommended for adult CHD patients in NYHA class II-IV, with systemic ventricular failure and dilation and prolonged QRS duration. Upgrading to CRT should be considered in CHD patients with systemic LV and permanent RV pacing causing LV dyssynchrony and dysfunction, and patients in NYHA class IV as a bridge to heart transplantation. In addition to remote monitoring of devices reducing adverse outcomes in ICD patients with acquired heart disease, it may be beneficial to $\mathrm{CHD}$ patients to detect and treat tachyarrhythmia early $[111,112]$.

\section{Heart transplantation}

The 2014 international society for heart transplantation reports in adult CHD patients, heart transplantation accounts for $10 \%$ of indications in patients aged 18 to 30 years [113]. Short-term outcomes are worse in adult CHD patients compared to non-CHD patients but late-term survival is improved and at ten years similar to that of patients with acquired heart disease [114,115]. Efficacy and clinical outcomes of heart transplantation vary depending on diagnosis made and the expertise of the center. It remains a challenge because of complex cardiac and vascular structure, multiple previous palliative and corrective surgeries and effect of other organs (kidney, liver and lungs) of chronic cardiac dysfunction or cyanosis with frequently increased pulmonary vascular resistance [86]. Timing for assessment for heart transplantation also remains a challenge because accurate prediction of prognosis is difficult and no single prognostic variable is able to provide a discriminatory capacity on the need and timing for heart transplantation $[115,116]$. Serial exercise testing and other variables such as hospitalization, clinically relevant arrhythmia, symptomatic HF, PLE and plastic bronchitis are useful in helping to determine CHD patients at need for heart transplantation. Pretransplant evaluation is recommended to assess vascular resistance, the presence of disease [42].

\section{Meta-analysis of hf therapy in CHD}

Significant advances in medical and surgical therapies has led to an increasing number of children born with CHD survive into adulthood. Depending upon underlying cardiac defect or a particular corrective surgery the patient might have undergone, this group of adult $\mathrm{CHC}$ patients constitute a new population with unique medical sequelae. With a lack of clinical trials to guide clinicians on specifically managing adult CHD patients with HF, most of the ESC medication guidelines for managing acute HF have been applied in adult CHD patients with HF after taking into account greater complexity and varied comorbidities usually on a case-by-case basis [42,95]. Moreover, adult CHD patients are at a higher risk of cardiac arrhythmias and other sequelae that could lead to SCD. In these patients, the value of ICD as a primary or secondary prevention therapy against SCD remains partially understood. Therefore, this meta-analysis aims to determine the therapeutic value (safety and efficacy) of HF medication and ICD therapies in management of HF in adult CHD patients.

\section{Study search and selection}

A systematic search was conducted in three major online databases (PubMed, EMBASE and Cochrane) for studies investigating clinical management of $\mathrm{HF}$ in $\mathrm{CHD}$ patients irrespective of publication language or year. To avoid overlooking studies that did not mention CHD in the title or abstract, the first 200 relevance-ranked articles retrieved with a full-text Google Scholar search were included. Additional studies were searched from references of the included papers and then subjected to the inclusion criteria. The search strategy included patient population of interest (have CHD or underwent corrective surgery) and intervention of interest (medical therapy - ACE-I, ARBs, beta-blockers or MRA - or device therapy - ICD). In particular, inclusion criteria was the study (a) enrolled CHD patients with systolic failure of the morphological systemic LV, RV, sub-pulmonary right ventricle or single ventricle, or at risk of SCD; and (b) patient were treated with medications or device therapy for primary or secondary prevention of SCD. Conference abstract of unpublished studies, case series and review articles were excluded. There was no restriction on the type of ICD (transvenous, epicardial or subcutaneous) and/or lead configuration (single chamber, dual-chamber, or cardiac resynchronization therapy).

\section{Data extraction and statistical analysis}

Two reviewers independently screened all the retrieved studies for eligibility and extracted data from the included studies. Extracted data included study characteristics, patient characteristics, followup duration, ICD and clinical outcomes (complications or death). Differences between reviewers were resolved through consensus. Therapeutic outcomes of interests reported in more than one study included parameters of RV function or morphology (RVEF, RVEDV and RV mass) for medical therapy, and appropriate shocks, complication and all-cause death for ICD therapy. For each outcome, summary statistics (mean and standard deviation) before and after the intervention was collected for treatment and control groups in RCT studies. Treatment effect was calculated by difference in means before and after intervention or between treatment and control (placebo) groups and $95 \%$ confidence interval (CI) for RV function outcomes, complications and deaths in medication and ICD patients respectively. Forests plots were used to visually examine heterogeneity between studies where $p$-value suggested evidence of heterogeneity. Pooled treatment effect and associated 95\% CI across the included studies was estimated for RCTs (treatment and control arms) and for observation studies (before and after treatment).

\section{Results}

In total, 234 articles met our search criteria. A review of reference lists of the included studies and review articles did not yield additional articles. After screening of titles and abstract, 54 studies were selected for full-text screening against the inclusion criteria. The main reason for exclusion of full-text articles was the lack of intervention with HF medication or no provided data for complications and/or death for patients implanted with ICD. Eventually, 17 studies $(\mathrm{N}=3,669)$ were included in this meta-analysis [76,117-132]. Tables 4,5 and 6 provide summaries of the final studies on medical and device therapy for HF in $\mathrm{CHD}$ patients considered for this systematic review and meta-analysis.

\section{Medical therapy}

In total, $182 \mathrm{CHD}$ patients with HF receiving medical therapy ARB, ACE-I, beta-blockers and/or MRAs were included from six studies [76, 117-121] published between 2005 and 2013. Across the included studies, the proportion of female patients was $34 \%$, 
Albakri A (2018) Heart failure in congenital heart disease: A review of clinical status and meta-analysis of diagnostic value of serum natriuretic peptides, and medical and device therapies

Table 4. Medical therapy for HF in CHD based on intrinsic myocardial dysfunction

\begin{tabular}{|c|c|c|c|}
\hline Type of HF & Morphology & Symptomatic & Medication \\
\hline \multirow{3}{*}{ Systemic ventricular failure } & LV $(\mathrm{EF}<40 \%)$ & Yes/No & RAAS blockers, beta-blockers, MRA, diuretics, digoxin \\
\hline & \multirow{2}{*}{$\mathrm{RV}(\mathrm{EF}<40 \%)$} & No & No medical treatment \\
\hline & & Yes & RAAS blockers, beta-blockers, MRA, diuretics, digoxin \\
\hline \multirow{2}{*}{ Sub-pulmonary ventricular failure } & \multirow{2}{*}{$\mathrm{LV} / \mathrm{RV}(\mathrm{EF}<40 \%)$} & No & No medical treatment \\
\hline & & Yes & Diuretics, MRA, pulmonary vasodilators \\
\hline \multirow{5}{*}{ Single ventricular failure } & Fontan circulation $(\mathrm{EF}<40 \%) / \mathrm{LV}$ & No & RAAs blockers, beta-blockers, MRA, digoxin \\
\hline & \multirow{2}{*}{$\mathrm{RV}, \mathrm{LV}$ and $\mathrm{RV}$} & No & No medical treatment \\
\hline & & Yes & RAAS blockers, beta-blockers, MRA, diuretics, digoxin \\
\hline & \multirow{2}{*}{ Persistent right-to-left-shunt } & No & No medical treatment \\
\hline & & Yes & Diuretics, agents to reduce afterload \\
\hline \multirow{2}{*}{ HF with preserved EF } & & No & No medical treatment \\
\hline & & Yes & Diuretics, beta-blocker, rate limiting calcium channel blocke \\
\hline
\end{tabular}

(EF: Ejection Fraction; HF: Heart Failure; MRA: Mineralocorticoid Receptor Antagonist; RAAS: Renin-Angiotensin-Aldosterone System)

Table 5. Summary of included studies on medical therapy

\begin{tabular}{|c|c|c|c|c|c|c|c|c|}
\hline 1st Author [Ref \#] & Year & Study Design & No. of Patients & $\begin{array}{l}\text { Age Mean } \pm \text { SD } \\
\text { (Years) }\end{array}$ & Female (n) & Medication Type & $\begin{array}{c}\text { Cardiac } \\
\text { Evaluation }\end{array}$ & FuP (Months) \\
\hline Dore et al. [76] & 2005 & Observation & 29 & $30.3 \pm 10.9$ & 5 & ARB & Echo & 4 \\
\hline Giardini et al. [117] & 2007 & Observation & 8 & $26(18-31)$ & 3 & $\beta$-blocker & MRI & 12 \\
\hline Therrien et al. [118] & 2008 & $\mathrm{RCT}$ & 17 & $26.4 \pm 5.2$ & 6 & ACE-I & MRI & 12 \\
\hline Bouallal et al. [119] & 2010 & Observation & 14 & $35(24-57)$ & 7 & $\beta$-blocker & MRI & 13 \\
\hline Dos et al. [120] & 2013 & RCT & 26 & $26.4 \pm 5.4$ & 10 & MRA & MRI & 12 \\
\hline Van der Bom et al. [121] & 2013 & $\mathrm{RCT}$ & 88 & $33.0 \pm 10$ & 31 & ARB & MRI/MDCT & 36 \\
\hline
\end{tabular}

(ARB: Angiotensin II Receptor; FuP: Follow-up Period; MDCT: Multi-Detector Computed Tomography; MRA: Mineralocorticoid Receptor Antagonists; MRI: Magnetic Resonance Imaging; RCT: Randomized Controlled Trial; SRV: Systemic RV Failure)

Table 6. Summary of included studies on ICD therapy

\begin{tabular}{|c|c|c|c|c|c|c|c|c|c|c|c|}
\hline \multirow[b]{2}{*}{ 1st Author [Ref \#] } & \multirow[b]{2}{*}{ Year } & \multirow[b]{2}{*}{$\mathbf{N}$} & \multirow[b]{2}{*}{ Age (years) } & \multirow[b]{2}{*}{ Male (n) } & \multirow[b]{2}{*}{$\begin{array}{c}\text { FuP } \\
\text { (Months) }\end{array}$} & \multicolumn{6}{|c|}{ Indication for ICD } \\
\hline & & & & & & RSCD & Syncope & LTVA & Pre-syncope & Palpitation & $\begin{array}{c}\text { Inducible } \\
\text { ST }\end{array}$ \\
\hline Stefanelli et al. [122] & 2002 & 27 & $14(6-26)$ & 13 & $32 \pm 29$ & 15 & 9 & 3 & & & \\
\hline Korte et al. [123] & 2004 & 20 & $16 \pm 6$ & & $51 \pm 31$ & 6 & 5 & 9 & & & \\
\hline Michael et al. [124] & 2007 & 5 & $24(19-35)$ & 3 & 20 & & & & & & \\
\hline Khairy et al. 125[] & 2008 & 37 & $28 \pm 7.6$ & 33 & $3.6(1.5,5.5)$ & & 8 & 11 & 3 & 12 & 7 \\
\hline Khairy et al. [126] & 2008 & 121 & $\begin{array}{c}33.3(21.3- \\
40.9)\end{array}$ & 72 & 44.4 & & 30 & 25 & 13 & 33 & 28 \\
\hline Celiker et al. [127] & 2010 & 28 & 11.6 & 18 & 31.2 & 8 & 11 & 3 & & & \\
\hline Koyak et al. [128] & 2012 & 136 & $41 \pm 13$ & 91 & $\begin{array}{c}4.6(0.01- \\
13.9)\end{array}$ & 31 & 6 & 72 & 5 & 1 & \\
\hline Lopez et al. [129] & 2012 & 6 & $52.8(38-65)$ & 4 & 60 & & & & & & \\
\hline Jin et al. [130] & 2013 & 15 & $14.5 \pm 5.4$ & 9 & $28.9 \pm 20.4$ & 7 & 2 & 6 & & & \\
\hline Jordan et al. [131] & 2014 & 3139 & $53.0 \pm 18.2$ & 1129 & & & & & & & \\
\hline Santharam et al. [132] & 2016 & 42 & $45.0(21-71)$ & 23 & 60 & & & 15 & & & \\
\hline
\end{tabular}

(LTVA: Life-Threatening Ventricular Arrhythmia; RSCD: Resuscitated Sudden Cardiac Death)

age ranged from 26.4 to 35.0 years with a mean of 29.5 years; mean follow up was 14.8 months range 4 to 36 months. Three studies were RCTs $[118,120,121]$ randomizing 131 patents to treatment $(n=66)$ or placebo study arms $(n=65)$ while the remaining three studies were observational $[76,117,119]$ investigating changes (pre- and posttreatment) in ventricular function and/or morphology assessed using echocardiography [76], MRI [117,118,120], MRI/multi-detected CT (MDCT) [121] or radionuclide ventriculography [119].

When the effect of medical therapy on RV function and morphology measured by echo, MRI or MDCT was pooled, the traditional HF medication led to positive improvement RV parameters but the improvement was not statistically significant. RVEF (difference in means: 0.23 ; $95 \% \mathrm{CI}$ : -0.037 to $0.496 ; \mathrm{p}=0.091$ ) (Figure 2); RVEDV (0.141; 95\% CI: -0.478 to $0.196 ; \mathrm{p}=0.411)$ (Figure 3), RVESV $(0.028$; $95 \%$ CI: -0.163 to $0.219 ; \mathrm{p}=0.775)$ (Figure 4$)$, and RVM $(-0.046 ; 95 \%$
CI: -0.230 to $0.138 ; p=0.627$ ) (Figure 5). These results suggest that medical therapy has limited beneficial effect to cardiac function and morphology in CHD patients with HF. However, the current findings are based on a limited number of RCTs, with a many studies adopting an observation design. Larger prospective RCTs are needed to confirm the effect of HF medication on patients with CHD.

We also evaluated heterogeneity across the included studies. Of all the medical outcomes on RV function assessed, only the mean difference in pre and post-treatment RVEF was found to have statistical significant heterogeneity $(p=0.036)$. However, it should be noted that due to the few studies and patients included, the power to detect heterogeneity across studies was reduced. Bayesian analyses were not carried out because there was no instance in which the overall result was statistically significant and evidence of heterogeneity would be insufficient. 
Albakri A (2018) Heart failure in congenital heart disease: A review of clinical status and meta-analysis of diagnostic value of serum natriuretic peptides, and medical and device therapies

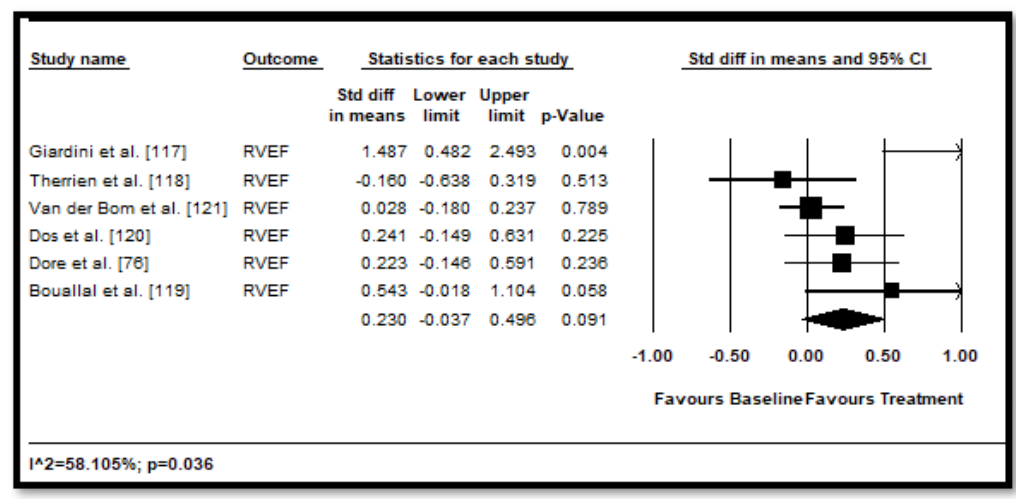

Figure 2. Pre- and post-treatment RVEF and $95 \%$ CI

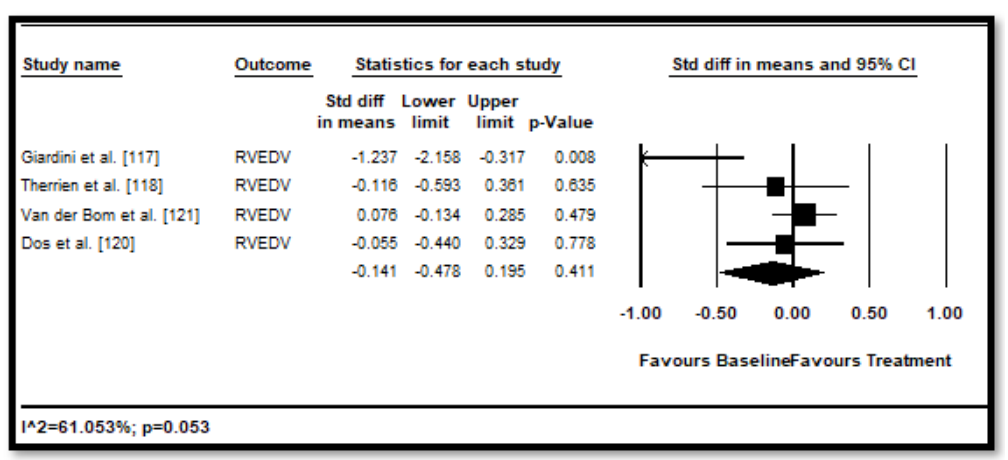

Figure 3. Pre- and post-treatment RVEDV and $95 \%$ CI

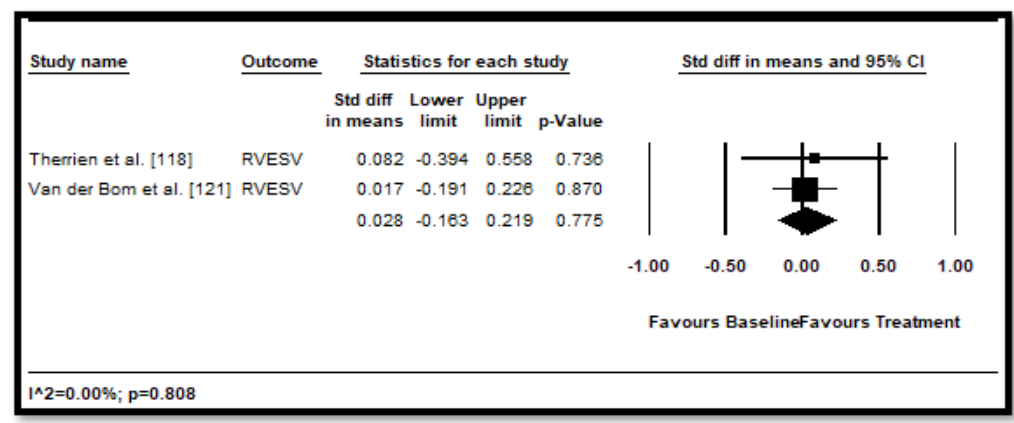

Figure 4. Pre- and post-treatment RVESV and $95 \%$ CI

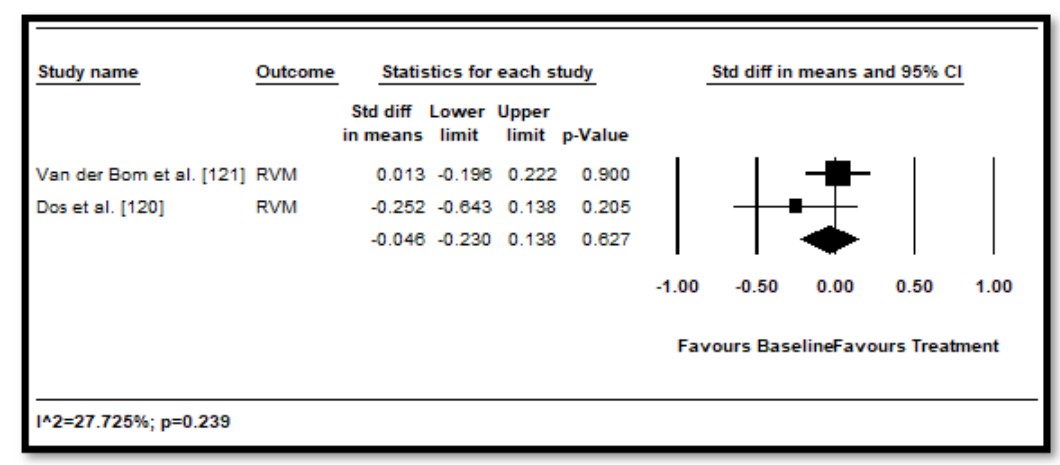

Figure 5. Pre- and post-treatment RVM and $95 \%$ CI 
Albakri A (2018) Heart failure in congenital heart disease: A review of clinical status and meta-analysis of diagnostic value of serum natriuretic peptides, and medical and device therapies

\section{Device therapy}

In total, 3,487 CHD patients with HF who underwent implantable cardioverter defibrillator (ICD) implantation were included from 11 studies published between 2002 and 2016 [122-132]. Table 5 displays a summary of the study, patient and outcomes characteristics in the 11 studies. In the included studies, patients were relatively young (mean age $=32.3$ years; range $=11.6$ to 55.1 ) followed for a mean of 33.57 months, range 3.6 to 60 months. In eight studies [122,125-128,130$132]$, more patients $(\mathrm{n}=2,146 ; 62 \%)$ had implantation for primary prevention. In five studies $[122,123,127,128,130]$, although there were multiple indications for ICD, the common ones were life threatening (or non-sustained) ventricular arrhythmias (47.8\%), resuscitated or aborted SCD $(29.7 \%)$, syncope $(14.6 \%)$, pre-syncope $(2.2 \%)$ and palpitations (0.4\%) and others (5.3\%). In pooled analysis of appropriate ICD interventions, more than a third of the patients $(34.1 \% ; 28.3-40.3)$ received appropriate ICD shocks in six studies [122,123,127-130,132] (Figure 6), while inappropriate ICD shocks occurred in over one in four patients (26.4\%; 22.4-30.9) in eight studies [122,123,125-128,130,132] (Figure 7). ICD complications occurred in 16.9\% (3.8-50.9) of the patients in six studies [122,125,127,129,130,131] (Figure 8). Although no ICD-related deaths were reported, all-cause death occurred in $13.3 \%$ (9.4-18.4) in seven studies [122-125,128-130] (Figure 9).

\section{Discussion of findings}

This meta-analysis sought to determine whether CHD patients with HF could benefit from the current medical and device therapies developed for HF. The results suggest HF medication have no significant

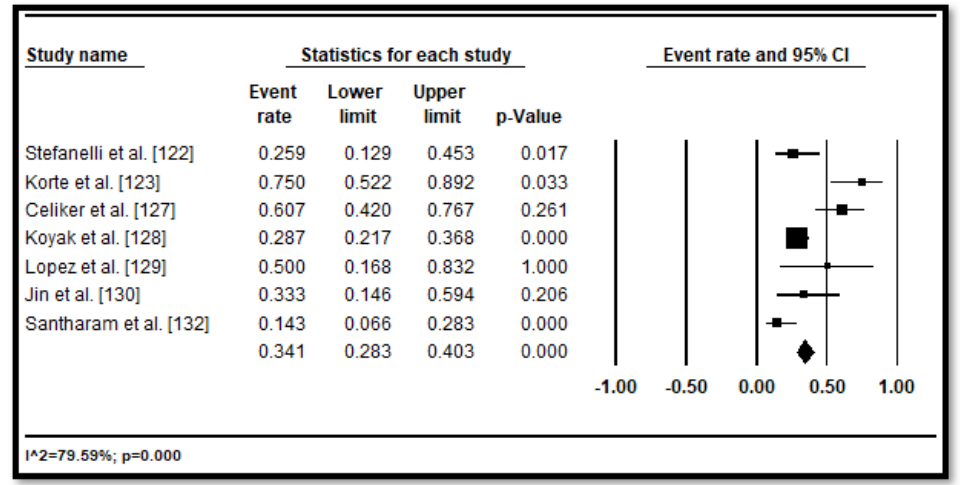

Figure 6. Forest plot of appropriate ICD shocks and 95\% CI

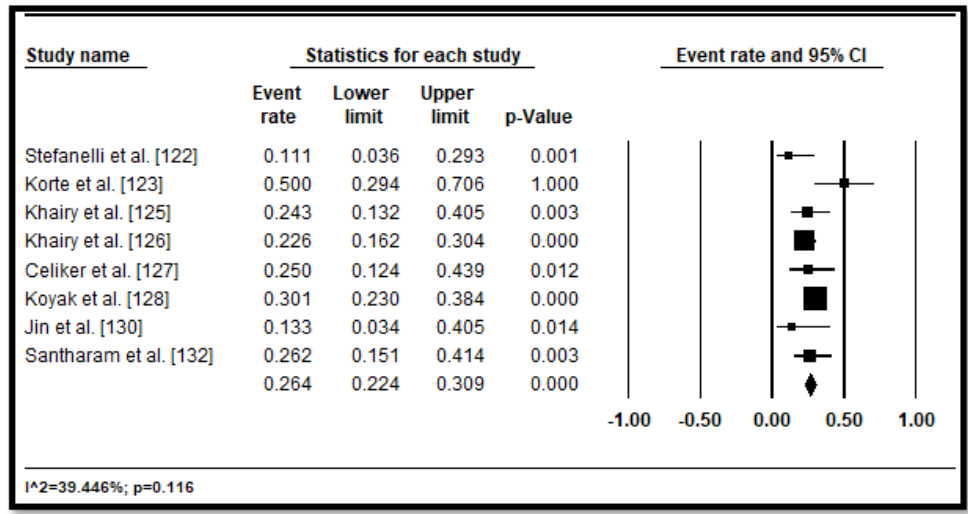

Figure 7. Forest plot of inappropriate ICD shocks and 95\% CI

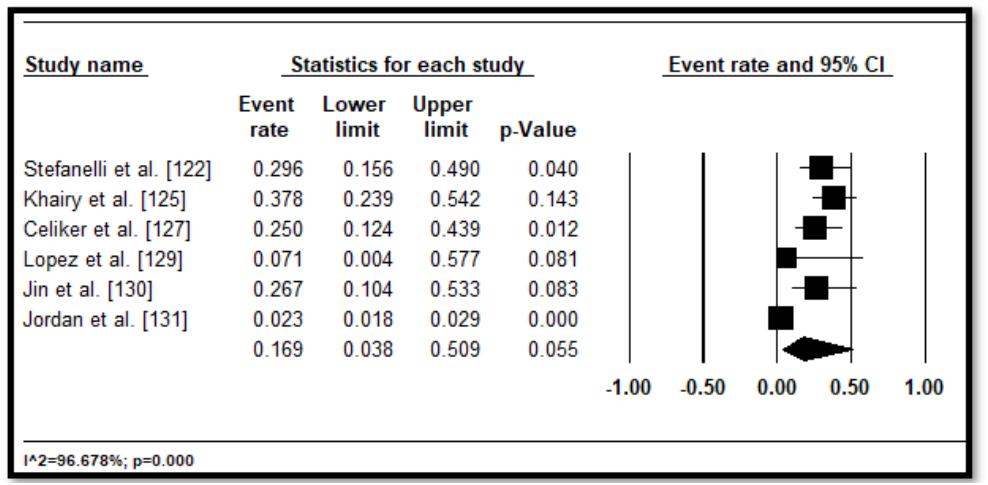

Figure 8. Forest plot of ICD complications and $95 \%$ CI 


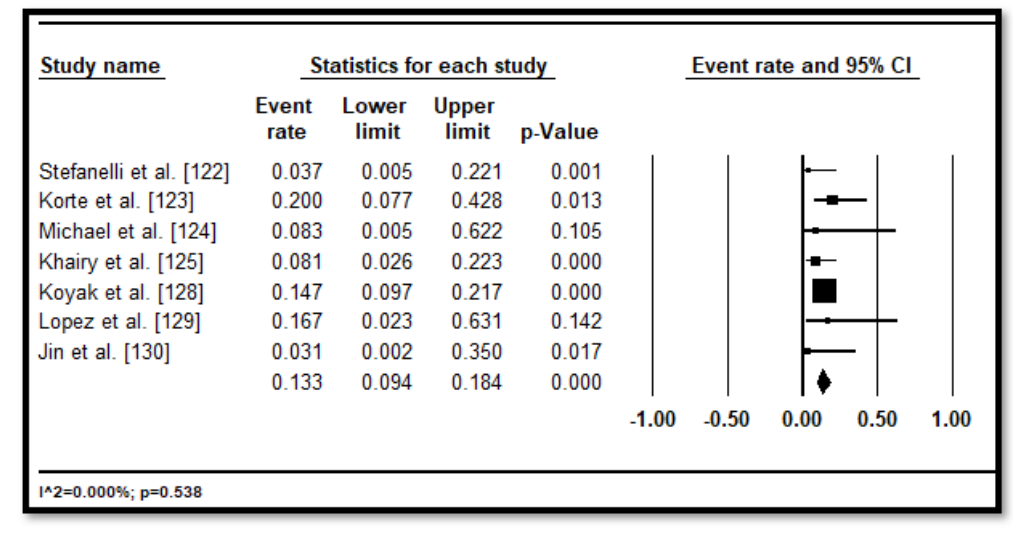

Figure 9. Forest plot of all-cause death and $95 \%$ CI

beneficial clinical outcomes in terms of improving ventricular function (RVEF, RVEDV, RVESV) as assessed by echocardiography, MRI or MDCT, or attenuate ventricular remodelling (changes in RVM) in adult CHD patients. Only four classes of medications (ARBs, ACE-I, beta-blockers and/or MRAs) were assessed on patients with complex cardiac defect (systolic failure of the morphological systemic RV). There was insufficient data for pooled analysis on other CHD conditions such as systolic failure of the sub-pulmonary RV or single ventricular.

The analysis of ARBs, ACE-I, beta-blockers and/or MRAs in CHD patients with HF is supported by previous evidence on non-congenital systemic LV failure in which they improve LV function, reduce ventricular mass/size, attenuate RV remodelling and reduce fibrosis [133-135], and dose-related decrease in deaths and hospitalization, and improvement in exercise tolerance [136,137]. Pathophysiological mechanisms for ventricular dysfunction in CHD patients is multifaceted but current evidence suggests the involvement of increased levels of neurohormones (norepinephrine and epinephrine) and fibrosis, the latter correlating with extent of ventricular dysfunction and higher incidences of adverse cardiac events such as syncope and arrhythmias [138-141]. Thus, the increase in neurohormonal and fibrosis in CHD patients with systemic RV suggests medication used for HF with LV failure may lead to improved outcomes in CHD patients with RV dysfunction. However, factors such as few studies, small sample size, increased numbers of patients lost to follow-up, and different degree of RV dysfunction may have affected the accuracy of outcomes.

Medical therapy in CHD patients with HF targets to relieve symptoms and improve RV function [42,95]. However, SCD affects 20$25 \%$ of these patients and device therapy is indicated for both primary and secondary prevention of SCD [142,143]. Most of the studies on device therapy have examined ICD, while very few (insufficient for a pooled analysis) have assessed cardiac resynchronization therapy and/ or cardiac transplantation. In our pooled analysis of ICD, CHD patients had a high rate of appropriate ICD interventions (34.1\%) and lower rates of ICD complications (16.9\%) and all-cause death (13.3\%) both in primary and secondary prevention. The present findings are consistent with that of a previous meta-analysis. Vehmeijer et al. [144] report high rates of appropriate ICD shocks and lower rates of mortality (10\% in a follow-up of 3.7 years) compared to the conventional ICD population of ischemic and non-ischemic cardiomyopathy patients of SCD in HF trial (22\% in 3.8 years) [145] but higher than in the average population (3\% in 3.6 years) [146]. However, the higher rates may be associated with ICD indicated for CHD patients with the highest risk for SCD and some patients who would have benefited from ICD sis not receive the device [144].
The present findings support current recommendations of the ESC on treatment of HF in adult CHD using ICD for the prevention of SCD. The recommendations are based on evidence from retrospective studies, expert opinions and extrapolation from other patient groups [42]. Despite higher rates of appropriate ICD shocks and lower mortality rate, the present analysis find the use of ICD in CHD patients can result in inappropriate ICD shocks and ICD-related complications in some patients. The rates have been reported to be higher in CHD patients (26\%) [144] compared to conventional HF populations (14\%) [145]. Most of these complications result from lead failure or dislodgement associated with complex anatomy in CHD patients, and the need for generator replacement and/or additional cardiac surgery, altogether destabilizing the leads. However, continued advancement in device and lead technology would reduce complications and inappropriate shocks from failed leads, improving the safety and efficacy of ICD therapy for selected CHD patients with HF.

\section{Conclusion}

In CHD patients, HF can develop early because of one or more residual substrates from an underlying or surgically corrected cardiac defect causing accumulated cardiac pressure, volume, tension and flow. Continuedimprovement in survival dueto successin surgical and medical management of patients born with CHD has led to an overall shift in the burden of care from pediatric to adult patients. Adult CHD patients have residual substrates predisposing them to early development of HF. In these patients, HF develops via three main pathogenic pathways: genetic, non-genetic or a combination of the two. Clinically, HF in adult CHD patients manifests as a triad of neurohormonal activation, cardiac abnormality and exercise intolerance. In a sub-population of adult $\mathrm{CHD}$, those with cyanotic conditions, clinical presentation is complicated because they may not exhibit typical HF symptoms and arrhythmias may be the first clinical manifestation of HF. Diagnosis of HF in CHD is based on assessment of patient's medical history, serum NP tests, ECG, cardiopulmonary tests and imaging (echo or cardiac MRI). HF in adult CHD lacks focused clinical management strategies and instead adopts consensus guidelines developed for HF in general. Although the efficacy of medical therapy in improving cardiac function is still inconclusive, it improves prognosis or alleviate symptoms. For $\mathrm{CHD}$ patients with systolic ventricular failure, exercise training, device therapy (for prevention of SCD), and ultimately heart transplantation can improve survival. However, heart transplantation is challenging because of difficulty in selecting deserving patients who will benefit from the procedure and the lack of prognostic variable to inform or monitor treatment efficacy. 
Albakri A (2018) Heart failure in congenital heart disease: A review of clinical status and meta-analysis of diagnostic value of serum natriuretic peptides, and medical and device therapies

\section{References}

1. Bolger AP, Sharma R, Li W, Leenarts M, Kalra PR, Kemp M, et al (2002) Neurohormonal activation and the chronic heart failure syndrome in adults with congenital heart disease. Circ 10: 92-99. [Crossref]

2. Webbs G, Williams RG (2001) 32nd Bethesda Conference. Care of the adult with congenital heart disease. J Am Coll Cardiol 37: 1161-1198. [Crossref]

3. Brickner ME, Hillis LD, Lange RA (2000) Congenital heart disease in adults. $N$ Engl J Med 342: 334-342. [Crossref]

4. Drenthen W, Pieper PG, Roos-Hesselink JW, van Lottum WA, Voors AA et al. (2007) Outcome of pregnancy in women with congenital heart disease: a literature review. $J$ Am Coll Cardiol 49: 2303-2311. [Crossref]

5. Van Der Bom T, Luijendijk P, Bouma BJ, Koolbergen DR, De Groot JR et al. (2011) Treatment of congenital heart disease: risk-reducing measures in young adults. Future cardiology 7: 227-240. [Crossref]

6. Wu FM, Ukomadu C, Odze RD, Valente AM, Mayer, Jr JE et al (2011) Liver disease in the patient with Fontan circulation. Congenital Heart Disease 6: 190-201. [Crossref]

7. Stout KK, Broberg CS, Book WM, Cecchin F, Chen JM et al. (2016) Chronic heart failure in congenital heart disease: a scientific statement from the American Heart Association. Circ 133: 770-801. [Crossref]

8. Montaña E, Khoury MJ, Cragan JD, Sharma S, Dhar P et al. (1996) Trends and outcomes after prenatal diagnosis of congenital cardiac malformations by fetal echocardiography in a well defined birth population, Atlanta, Georgia, 1990-1994. J Am Coll Cardiol 28: 1805-1809. [Crossref]

9. Mitchell SC, Korones SB, Berendes HW (1971) Congenital heart disease in 56,109 births incidence and natural history. Circ 43: 323-332. [Crossref]

10. Hoffman JI, Kaplan S (2002) The incidence of congenital heart disease. J Am Coll Cardiol 39: 1890-900. [Crossref]

11. Warnes CA, Liberthson R, Danielson GK, Dore A, Harris L et al. (2001) Task force 1: the changing profile of congenital heart disease in adult life $J$ Am Coll Cardiol 37: 1170-1175. [Crossref]

12. Fahed AC, Roberts AE, Mital S, Lakdawala NK (2014) Heart failure in congenital heart disease: a confluence of acquired and congenital. Heart Fail Clin 10: 219-227. [Crossref]

13. Webb CL, Jenkins KJ, Karpawich PP, Bolger AF, Donner RM, et al. (2002) Congenital Cardiac Defects Committee of the American Heart Association Section on Cardiovascular Disease in the Young. Collaborative care for adults with congenital heart disease. Circ 105: 2318-2323. [Crossref]

14. Warnes CA, Williams RG, Bashore TM, Child JS, Connolly HM et al. (2008) ACC AHA 2008 guidelines for the management of adults with congenital heart disease: a report of the American college of cardiology/American Heart Association task force on practice guidelines (writing committee to develop guidelines on the management of adults with congenital heart disease) developed in collaboration with the American Society of Echocardiography, Heart Rhythm Society, International Society for Adult Congenital Heart Disease, Society for Cardiovascular Angiography and Interventions .... J Am Coll Cardiol 52: e143-263. [Crossref]

15. Greutmann M, Tobler D (2012) Changing epidemiology and mortality in adul congenital heart disease: looking into the future. Future Cardiology 8: 171-177. [Crossref]

16. Khairy P, Ionescu-Ittu R, Mackie AS, Abrahamowicz M, Pilote L et al. (2010) Changing mortality in congenital heart disease. J Am Coll Cardiol 56: 1149-1157. [Crossref]

17. Norozi K, Wessel A, Alpers V, Arnhold JO, Geyer S et al. (2006) Incidence and risk distribution of heart failure in adolescents and adults with congenital heart disease after cardiac surgery. Am J Cardiol 97: 1238-1243. [Crossref]

18. Verheugt CL, Uiterwaal CS, van der Velde ET, Meijboom FJ, Pieper PG et al. (2010) Mortality in adult congenital heart disease. Eur Heart J 31: 1220-1229. [Crossref]

19. Parekh DR (2011) A review of heart failure in adults with congenital heart disease. Methodist DeBakey cardiovascular journal 7: 26-32. [Crossref]

20. Fahed AC, Gelb BD, Seidman JG, Seidman CE (2013) Genetics of congenital heart disease: the glass half empty. Circ Res 112: 707-720. [Crossref]

21. Gelb B, Brueckner M, Chung W, Goldmuntz E, Kaltman J et al. (2013) The congenital heart disease genetic network study: rationale, design, and early results. Circ Res 112 698-706. [Crossref]

22. Zaidi S, Choi M, Wakimoto H, Ma L, Jiang J et al. (2013) De novo mutations in histone-modifying genes in congenital heart disease. Nature 498: 220. [Crossref]
23. Cavusoglu Y, Ata N, Timuralp B, Gorenek B, Goktekin O et al. (2003) Noncompaction of the ventricular myocardium: report of two cases with bicuspid aortic valve demonstrating poor prognosis and with prominent right ventricular involvement. Echocardiography 20: 379-383. [Crossref]

24. Wessels MW, De Graaf BM, Cohen-Overbeek TE, Spitaels SE, de Groot-de Laat LE et al. (2008) A new syndrome with noncompaction cardiomyopathy, bradycardia, pulmonary stenosis, atrial septal defect and heterotaxy with suggestive linkage to chromosome 6p. Human genetics 122: 595-603. [Crossref]

25. Puley G, Siu S, Connelly M, Harrison D, Webb G et al. (1999) Arrhythmia and survival in patients $>18$ years of age after the Mustard procedure for complete transposition of the great arteries. Am J Cardiol 83: 1080-1084. [Crossref]

26. Ichida F, Tsubata S, Bowles KR, Haneda N, Uese K et al. (2001) Novel gene mutations in patients with left ventricular non-compaction or Barth syndrome. Circ 103: 12561263. [Crossref]

27. Zomer AC, Vaartjes I, Van Der Velde ET, De Jong HM, Konings TC et al. (2013) Heart failure admissions in adults with congenital heart disease; risk factors and prognosis. Int J Cardiol 168: 2487-2493. [Crossref]

28. Charron F, Paradis P, Bronchain O, Nemer G, Nemer M (1999) Cooperative interaction between GATA-4 and GATA-6 regulates myocardial gene expression. Mol Cell Biol 19: 4355-4365. [Crossref]

29. Aries A, Paradis P, Lefebvre C, Schwartz RJ, Nemer M (2004) Essential role of GATA4 in cell survival and drug-induced cardiotoxicity. Proc Natl Acad Sci 101: 6975-6980. [Crossref]

30. Epstein JA, Rader DJ, Parmacek MS (2000) Perspective: cardiovascular disease in the postgenomic era-lessons learned and challenges ahead. Endocrinology 143: 2045 2050. [Crossref]

31. Jalal Z, Iriart X, De Lédinghen V, Barnetche T, Hiriart JB et al. (2015) Liver stiffness measurements for evaluation of central venous pressure in congenital heart diseases. Heart 101: 1499-1504. [Crossref]

32. Ford RM, Book W, Spivey JR (2015) Liver disease related to the heart. Transplant Rev 29: 33-37. [Crossref]

33. Lindsay I, Johnson J, Everitt MD, Hoffman J, Yetman AT (2015) Impact of liver disease after the Fontan operation. Am J Cardiol 115: 249-252. [Crossref]

34. Bradley E, Hendrickson B, Daniels C (2015) Fontan liver disease: review of an emerging epidemic and management options. Curr Treat Options Cardiovasc Med 17 51. [Crossref]

35. Pundi KN, Johnson JN, Dearani JA, Pundi KN, Li Z et al. (2015) 40-year follow-up after the Fontan operation: long-term outcomes of 1,052 patients. $J$ Am Coll Cardiol 66: 1700-1710. [Crossref]

36. Schumacher KR, Stringer KA, Donohue JE, Yu S, Shaver A et al. (2015) Fontanassociated protein-losing enteropathy and plastic bronchitis. J Pediatr 166: 970-977. [Crossref]

37. Saiki H, Kuwata S, Kurishima C, Iwamoto Y, Ishido H et al. (2016) Prevalence, implication, and determinants of worsening renal function after surgery for congenita heart disease. Heart Vessels 31: 1313-1318. [Crossref]

38. Jensen AS, Johansson PI, Idorn L, Sørensen KE, Thilén U et al.(2013) The haematocritan important factor causing impaired haemostasis in patients with cyanotic congenita heart disease. Int J Cardiol 167: 1317-1321. [Crossref]

39. Budts W (2005) Eisenmenger syndrome: medical prevention and managemen strategies. Expert Opin Pharmacother 6: 2047-2060. [Crossref]

40. Diller GP, Dimopoulos K, Okonko D, Li W, Babu-Narayan SV, Broberg CS et al (2005) Exercise intolerance in adult congenital heart disease: comparative severity, correlates, and prognostic implication. Circ 112: 828-835. [Crossref]

41. McMurray, J.J., Adamopoulos, S., Anker, S.D., Auricchio, A., Böhm, M., Dickstein, K., Falk, V., Filippatos, G., Fonseca, C. and Gomez-Sanchez, M.A., 2012. ESC Guidelines for the diagnosis and treatment of acute and chronic heart failure 2012: The Task Force for the Diagnosis and Treatment of Acute and Chronic Heart Failure 2012 of the European Society of Cardiology. Developed in collaboration with the Heart Failure Association (HFA) of the ESC. Eur Heart $J$ 14: 803-869. [Crossref]

42. Budts W, Roos-Hesselink J, Rädle-Hurst T, Eicken A, McDonagh TA et al. (2016) Treatment of heart failure in adult congenital heart disease: a position paper of the Working Group of Grown-Up Congenital Heart Disease and the Heart Failure Association of the European Society of Cardiology. Eur Heart J 37: 1419-1427. [Crossref] 
Albakri A (2018) Heart failure in congenital heart disease: A review of clinical status and meta-analysis of diagnostic value of serum natriuretic peptides, and medical and device therapies

43. Eindhoven JA, van den Bosch AE, Boersma E, Roos-Hesselink JW (2013) The usefulness of brain natriuretic peptide in simple congenital heart disease-a systematic review. Cardiol Young. 23: 315-324. [Crossref]

44. Alonso-Gonzalez R, Dimopoulos K (2013) Biomarkers in congenital heart disease: do natriuretic peptides hold the key? Expert Rev Cardiovasc Ther 11: 773-784. [Crossref]

45. Eindhoven JA, van den Bosch AE, Ruys TP, Opić P, Cuypers JA et al. (2013) N-termina pro-B-type natriuretic peptide and its relationship with cardiac function in adults with congenital heart disease. J Am Coll Cardiol 62: 1203-1212. [Crossref]

46. Nagaya N, Nishikimi T, Uematsu M, Kyotani S, Satoh T et al. (1998) Secretion patterns of brain natriuretic peptide and atrial natriuretic peptide in patients with or without pulmonary hypertension complicating atrial septal defect. Am Heart $J$ 136: 297-301. [Crossref]

47. Schoen SP, Zimmermann T, Kittner T, Braun MU, Fuhrmann J et al. (2007) NTproBNP correlates with right heart haemodynamic parameters and volumes in patients with atrial septal defects. Eur J Heart Fail 9: 660-666. [Crossref]

48. Norozi K, Buchhorn R, Kaiser C, Hess G, Grunewald RW et al. (2005) Plasma $\mathrm{N}$-terminal pro-brain natriuretic peptide as a marker of right ventricular dysfunction in patients with tetralogy of Fallot after surgical repair. Chest 128: 2563-2570. [Crossref]

49. Trojnarska O, Szyszka A, Gwizdała A, Siniawski A, Oko-Sarnowska Z et al. (2006) The BNP concentrations and exercise capacity assessment with cardiopulmonary stress test in patients after surgical repair of Fallot's tetralogy. Int J Cardiol 110: 86-92. [Crossref]

50. Norozi K, Buchhorn R, Bartmus D, Alpers V, Arnhold JO et al. (2006) Elevated brain natriuretic peptide and reduced exercise capacity in adult patients operated on for tetralogy of Fallot is due to biventricular dysfunction as determined by the myocardial performance index. Am J Cardiol 97: 1377-1382. [Crossref]

51. Chow PC, Cheung EW, Chong CY, Lun KS, Yung TC et al. (2008) Brain natriuretic peptide as a biomarker of systemic right ventricular function in patients with transposition of great arteries after atrial switch operation. Int J Cardiol 127: 192-197. [Crossref]

52. Westhoff-Bleck M, Podewski E, Tutarel O, Wenzel D, Cappello C et al. (2013) Prognostic value of NT-proBNP in patients with systemic morphological right ventricles: a single-center experience. Int J Cardiol 169: 433-438. [Crossref]

53. Koch AM, Zink S, Singer H, Dittrich S (2008) B-type natriuretic peptide levels in patients with functionally univentricular hearts after total cavopulmonary connection. Eur J Heart 10: 60-62. [Crossref]

54. Hsu JH, Oishi PE, Keller RL, Chikovani O, Karl TR et al. (2008) Perioperative B-type natriuretic peptide levels predict outcome after bidirectional cavopulmonary anastomosis and total cavopulmonary connection. J Thorac Cardiovasc Surg 135: 746753. [Crossref]

55. Holmgren D, Westerlind A, Berggren H, Lundberg PA, Wåhlander H (2008) Increased natriuretic peptide type B level after the second palliative step in children with univentricular hearts with right ventricular morphology but not left ventricular morphology. Pediatr Cardiol 29: 786-792. [Crossref]

56. Ohuchi H, Takasugi H, Ohashi H, Yamada O, Watanabe K et al. (2004) Abnormalities of neurohormonal and cardiac autonomic nervous activities relate poorly to functional status in Fontan patients. Circ 110: 2601-2608. [Crossref]

57. Flachskampf FA, Wouters PF, Edvardsen T, Evangelista A, Habib G et al. (2014) Recommendations for transoesophageal echocardiography: EACVI update 2014. Eur Heart J Cardiovasc Imaging 2014 Feb 19;15(4):353-65. [Crossref]

58. Ait-Ali L, Siciliano V, Passino C, Molinaro S, Pasanisi E et a;. (2014) Role of stress echocardiography in operated Fallot: feasibility and detection of right ventricular response. JAm Soc Echocardiogr 27: 1319-1328. [Crossref]

59. Picano E, Pellikka PA (2013) Stress echo applications beyond coronary artery disease. Eur Heart J 35: 1033-1040. [Crossref]

60. Kilner PJ, Geva T, Kaemmerer H, Trindade PT, Schwitter J, Webb GD (2010). Recommendations for cardiovascular magnetic resonance in adults with congenital heart disease from the respective working groups of the European Society of Cardiology. Eur Heart J 31: 794-805. [Crossref]

61. Valente AM, Cook S, Festa P, Ko HH, Krishnamurthy R et al. (2014) Multimodality imaging guidelines for patients with repaired tetralogy of Fallot: a report from the American Society of Echocardiography: developed in collaboration with the Society for Cardiovascular Magnetic Resonance and the Society for Pediatric Radiology $\mathrm{J}$ Am Soc Echocardiogr 27: 111-141. [Crossref]

62. Holzer R, Beekman R, Benson L, Bergersen L, Jayaram N et al. (2016) Characteristics and safety of interventions and procedures performed during catheterisation of patients with congenital heart disease: early report from the national cardiovascular data registry. Cardiol Young 26: 1202-1212. [Crossref]
63. Inuzuka R, Diller GP, Borgia F, Benson L, Tay EL et al. (2012) Comprehensive use of cardiopulmonary exercise testing identifies adults with congenital heart disease at increased mortality risk in the medium term. Circ 125: 250-259. [Crossref]

64. Nathan AS, Loukas B, Moko L, Wu F, Rhodes J et al. (2014) Exercise oscillatory ventilation in patients with Fontan physiology. Circ Heart Fail 8: 304-311. [Crossref]

65. Kunii Y, Kamada M, Ohtsuki S, Araki T, Kataoka K et al. (2003) Plasma brain natriuretic peptide and the evaluation of volume overload in infants and children with congenital heart disease. Acta Med Okayama 57: 191-198. [Crossref]

66. Suda K, Matsumura M, Matsumoto M (2003) Clinical implication of plasma natriuretic peptides in children with ventricular septal defect. Pediatrics international 45: 249254. [Crossref]

67. Trojnarska O, Szyszka A, Gwizdala A, Oko-Sarnowska Z, Katarzynski S et al. (2006) Evaluation of exercise capacity with cardiopulmonary exercise testing and type B natriuretic peptide concentrations in adult patients with patent atrial septal defect. Cardiol 106: 154-160. [Crossref]

68. Chen LP, Wei TM, Wang LX (2007) Relationship between pericardial fluid B-type natriuretic peptide and ventricular structure and function. Arch Med Res 38: 326-329. [Crossref]

69. Eerola A, Pihkala JI, Boldt T, Mattila IP, Poutanen T et al. (2007) Hemodynamic improvement is faster after percutaneous ASD closure than after surgery. Catheter Cardiovasc Interv 69: 432-441. [Crossref]

70. Mainwaring RD, Parise C, Wright SB, Juris AL, Achtel RA et al. (2007) Brain natriuretic peptide levels before and after ventricular septal defect repair. Ann Thorac Surg 84: 2066-2069. [Crossref]

71. Oyamada J, Toyono M, Shimada S, Aoki-Okazaki M, Tamura M et al. (2008) Noninvasive Estimation of Left Ventricular End-Diastolic Pressure Using Tissue Doppler Imaging Combined with Pulsed-Wave Doppler Echocardiography in Patients with Ventricular Septal Defects: A Comparison with the Plasma Levels of the B-Type Natriuretic Peptide. Echocardiography 25: 270-277. [Crossref]

72. Toyono M, Harada K, Tamura M, Aoki-Okazaki M, Shimada S et al. (2008) Paradoxica relationship between B-type natriuretic peptide and pulmonary vascular resistance in patients with ventricular septal defect and concomitant severe pulmonary hypertension. Pediatr Ccardiol 29: 65-69. [Crossref]

73. Eerola A, Jokinen E, Pihkala JI (2009) Serum levels of natriuretic peptides in children with various types of loading conditions. . Scand Cardiovasc J 43: 187-193. [Crossref]

74. Uz O, Aparc1 M, Acar G, Kardesoglu E, Kaplan O et al. (2011) Association of Plasma B-Type Natriuretic Peptide Levels with Shunt Size in Young Adults with Atrial Septal Defect. Echocardiography 28: 243-247. [Crossref]

75. Jan SL, Fu YC, Hwang B, Lin SJ (2012) B-type natriuretic peptide in children with atrial or ventricular septal defect: a cardiac catheterization study. Biomarkers 17: 166171. [Crossref]

76. Dore A, Houde C, Chan KL, Ducharme A, Khairy P et al. (2005) Angiotensin receptor blockade and exercise capacity in adults with systemic right ventricles: a multicenter, randomized, placebo-controlled clinical trial. Circ 112: 2411-2416. [Crossref]

77. Chow PC, Cheung EW, Chong CY, Lun KS, Yung TC et al. (2008) Brain natriuretic peptide as a biomarker of systemic right ventricular function in patients with transposition of great arteries after atrial switch operation. Int J Cardiol 127: 192-197. [Crossref]

78. Garg R, Raman SV, Hoffman TM, Hayes J, Daniels CJ (2008) Serum markers of systemic right ventricular function and exercise performance. Pediatr Cardiol 29: 641648. [Crossref]

79. Koch AM, Zink S, Singer H (2008) B-type natriuretic peptide in patients with systemic right ventricle. Cardiology 110: 1-7. [Crossref]

80. Koželj M, Prokšelj K, Berden P, Jan M, Osredkar J et al. (2008) The syndrome of cardiac failure in adults with congenitally corrected transposition. Cardiol Young 18 599-607. [Crossref]

81. Vogt M, Kühn A, Wiese J, Eicken A, Hess J et al. (2009) Reduced contractile reserve of the systemic right ventricle under dobutamine stress is associated with increased brain natriuretic peptide levels in patients with complete transposition after atrial repair. Eur J Echocardiogr 10: 691-694. [Crossref]

82. Plymen CM, Hughes ML, Picaut N, Panoulas VF, MacDonald ST et al. (2010) The relationship of systemic right ventricular function to ECG parameters and NT-proBNP levels in adults with transposition of the great arteries late after Senning or Mustard surgery. Heart 96: 1569-1573. [Crossref] 
Albakri A (2018) Heart failure in congenital heart disease: A review of clinical status and meta-analysis of diagnostic value of serum natriuretic peptides, and medical and device therapies

83. Schaefer A, Tallone EM, Westhoff-Bleck M, Klein G, Drexler H et a;. (2010) Relation of diastolic and systolic function, exercise capacity and brain natriuretic peptide in adults after Mustard procedure for transposition of the great arteries. Cardiology 117: 112-117. [Crossref]

84. Ishii H, Harada K, Toyono M, Tamura M, Takada G (2005) Usefulness of exerciseinduced changes in plasma levels of brain natriuretic peptide in predicting right ventricular contractile reserve after repair of tetralogy of Fallot. Am J Cardiol 95: 1338 1343. [Crossref]

85. Dodge-Khatami A, Büchel EV, Knirsch W, Kadner A, Rousson V et a;. (2006) Brain natriuretic peptide and magnetic resonance imaging in tetralogy with right ventricular dilatation. Ann Thorac Surg 82: 983-988. [Crossref]

86. Cheung EW, Lam WW, Chiu CS, Chau AK, Cheung SC et al. (2007) Plasma brain natriuretic peptide levels, right ventricular volume overload and exercise capacity in adolescents after surgical repair of tetralogy of Fallot. Int J Cardiol 121: 155-162. [Crossref]

87. Festa P, Ait-Ali L, Prontera C, De Marchi D, Fontana M ey al. (2007) Amino-terminal fragment of pro-brain natriuretic hormone identifies functional impairment and right ventricular overload in operated tetralogy of Fallot patients. Pediatr Cardiol 28: 339345. [Crossref]

88. Khositseth A, Manop J, Khowsathit P, Siripornpitak S, Pornkul R et al. (2007) $\mathrm{N}$-terminal pro-brain natriuretic peptide as a marker in follow-up patients with tetralogy of Fallot after total correction. Pediatr Cardiol 28: 333-338. [Crossref]

89. Wand O, Perles Z, Rein AJ, Algur N, Nir A (2007) Clinical, echocardiographic and humoral status of patients following repair of tetralogy of Fallot: comparison of the second to the first decade. Isr Med Assoc J 9: 843. [Crossref]

90. Apitz C, Sieverding L, Latus H, Uebing A, Schoof S et al. (2009) Right ventricular dysfunction and B-type natriuretic peptide in asymptomatic patients after repair for tetralogy of Fallot. Pediatr Cardiol 30: 898-904. [Crossref]

91. Cetin İ, Tokel K, Varan B, Örün U, Așlamaci S (2009) Evaluation of right ventricular function by using tissue Doppler imaging in patients after repair of tetralogy of Fallot. Echocardiography 26: 950-957. [Crossref]

92. Van den Berg J, Strengers JL, Wielopolski PA, Hop WC, Meijboom FJ et al. (2009) Assessment of biventricular functional reserve and NT-proBNP levels in patients with RV volume overload after repair of tetralogy of Fallot at young age. Int J Cardiol 133: 364-370. [Crossref]

93. Tatani SB, Carvalho AC, Andriolo A, Rabelo R, Campos O et al. (2010) Echocardiographic parameters and brain natriuretic peptide in patients after surgical repair of tetralogy of Fallot. Echocardiography 27: 442-447. [Crossref]

94. Eindhoven JA, van den Bosch AE, Jansen PR, Boersma E, Roos-Hesselink JW (2012) The usefulness of brain natriuretic peptide in complex congenital heart disease: a systematic review. J Am Coll Cardiol 60: 2140-2149. [Crossref]

95. Ponikowski P, Voors AA, Anker SD, Bueno H, Cleland JG et al. (2016) 2016 ESC Guidelines for the diagnosis and treatment of acute and chronic heart failure: The Task Force for the diagnosis and treatment of acute and chronic heart failure of the European Society of Cardiology (ESC). Developed with the special contribution of the Heart Failure Association (HFA) of the ESC. Eur J Heart Fail 2016 Aug;18(8):891-975. [Crossref]

96. Plante E, Lachance D, Champetier S, Drolet MC, Roussel É et al. (2008) Benefits of long-term $\beta$-blockade in experimental chronic aortic regurgitation. Am J Physiol Heart Circ Physiol 294: H1888-H1895. [Crossref]

97. Zendaoui A, Lachance D, Roussel É, Couet J, Arsenault M. Usefulness of carvedilol in the treatment of chronic aortic valve regurgitation. Circ Heart Fail 4: 207-213. [Crossref]

98. Ennis DB, Rudd-Barnard GR, Li B, Fonseca CG, Young AA et al. (2010) Changes in mitral annular geometry and dynamics with $\beta$-blockade in patients with degenerative mitral valve disease. Circ Cardiovasc Imaging 3: 687-693. [Crossref]

99. Corrà U, Giannuzzi P, Adamopoulos S, Bjornstad H, Bjarnason-Weherns $\mathrm{B}$ et al (2005) Executive summary of the position paper of the Working Group on Cardiac Rehabilitation and Exercise Physiology of the European Society of Cardiology (ESC): core components of cardiac rehabilitation in chronic heart failure. Eur $J$ Cardiovasc Prev Rehabil 12: 321-325. [Crossref]

100. O'Connor CM, Whellan DJ, Lee KL, Keteyian SJ, Cooper LS et al. (2009) Efficacy and safety of exercise training in patients with chronic heart failure: HF-ACTION randomized controlled trial. Jama 301: 1439-1450. [Crossref]

101. Van Der Bom T, Winter MM, Knaake JL, Cervi E, De Vries LS et al. (2015) Longterm benefits of exercise training in patients with a systemic right ventricle. Int $J$ Cardiol 179: 105-111. [Crossref]
102. Duppen N, Geerdink LM, Kuipers IM, Bossers SS, Koopman LP et al. (2015) Regional Ventricular Performance and Exercise Training in Children and Young Adults After Repair of Tetralogy of FallotCLINICAL PERSPECTIVE: Randomized Controlled Pilot Study. Circ Cardiovasc Imaging 8: e002006. [Crossref]

103. Duppen N, Kapusta L, de Rijke YB, Snoeren M, Kuipers IM et al. (2015) The effect of exercise training on cardiac remodelling in children and young adults with corrected tetralogy of Fallot or Fontan circulation: a randomized controlled trial. Int J Cardiol. 179: 97-104. [Crossref]

104. Gierat-Haponiuk K, Haponiuk I, Szalewska D, Chojnicki M, Jaworski R et al. (2015) , Niedoszytko P, Leszczyńska K, Bakuła S. Effect of complex cardiac rehabilitation on physical activity and quality of life during long-term follow-up after surgical correction of congenital heart disease. Polish Heart Journal 73: 267-273. [Crossref]

105. Koyak Z, Harris L, de Groot JR, Silversides CK, Oechslin EN et al. (2012) Sudden cardiac death in adult congenital heart disease. Circ 126: 1944-1954. [Crossref]

106. Triedman JK (2008) Should patients with congenital heart disease and a systemic ventricular ejection fraction less than $30 \%$ undergo prophylactic implantation of an ICD? Response to Triedman: Implantable Cardioverter Defibrillator Implantation Guidelines Based Solely on Left Ventricular Ejection Fraction Do Not Apply to Adults With Congenital Heart Disease. Circ Arrhythm Electrophysiol 1: 307-316. [Crossref]

107. Tracy CM, Epstein AE, Darbar D, DiMarco JP, Dunbar SB et al. (2012) 2012 ACCF/ AHA/HRS focused update of the 2008 guidelines for device-based therapy of cardiac rhythm abnormalities: a report of the American College of Cardiology Foundation/ American Heart Association Task Force on Practice Guidelines. J Am Coll Cardiol 60: 1297-313. [Crossref]

108. Silka MJ, Bar-Cohen Y (2008) Should patients with congenital heart disease and a systemic ventricular ejection fraction less than $30 \%$ undergo prophylactic implantation of an ICD? Circ Arrhythm Electrophysio 1: 298-306. [Crossref]

109. Cleland JG, Daubert JC, Erdmann E, Freemantle N, Gras D et al. (2005) The effect of cardiac resynchronization on morbidity and mortality in heart failure. $N$ Engl $\mathrm{J} \mathrm{Med}$ 352: 1539-1549. [Crossref]

110. Moss AJ, Hall WJ, Cannom DS, Klein H, Brown MW et al. (2009) Cardiacresynchronization therapy for the prevention of heart-failure events. $N$ Engl J Med 361: 1329-1338. [Crossref]

111. Akar JG, Bao H, Jones P, Wang Y, Varosy P et al. (2015) Use of remote monitoring is associated with lower risk of adverse outcomes among patients with implanted cardiac defibrillators. Circ Arrhythm Electrophysio 8: 1173-1180. [Crossref]

112. Nagel B, Janousek J, Koestenberger M, Maier R, Sauseng W et al. (2014) Remote monitoring leads to early recognition and treatment of critical arrhythmias in adults after atrial switch operation for transposition of the great arteries. Circ J 78: 450-456. [Crossref]

113. Lund LH, Edwards LB, Kucheryavaya AY, Benden C, Christie JD et al. (2014) The registry of the International Society for Heart and Lung Transplantation: thirty-first official adult heart transplant report-2014; focus theme: retransplantation. J Heart Lung Transplant 33: 996-1008. [Crossref]

114. Goldberg SW, Fisher SA, Wehman B, Mehra MR (2014) Adults with congenital hear disease and heart transplantation: optimizing outcomes. J Heart Lung Transplant 33: 873-877. [Crossref]

115. Burchill LJ, Edwards LB, Dipchand AI, Stehlik J, Ross HJ (2014) Impact of adult congenital heart disease on survival and mortality after heart transplantation. $J$ Heart Lung Transplant 33: 1157-1163. [Crossref]

116. Houyel L, To-Dumortier N, Lepers Y, Petit J, Roussin R et al. (2017) Heart transplantation in adults with congenital heart disease. Arch Cardiovasc Dis 2017. [Crossref]

117. Giardini A, Lovato L, Donti A, Formigari R, Gargiulo G et al. (2007) A pilot study on the effects of carvedilol on right ventricular remodelling and exercise tolerance in patients with systemic right ventricle. Int J Cardiol 114: 241-246. [Crossref]

118. Therrien J, Provost Y, Harrison J, Connelly M, Kaemmerer H et al. (2008) Effect of angiotensin receptor blockade on systemic right ventricular function and size: a small, randomized, placebo-controlled study. Int J Cardiol 129: 187-192. [Crossref]

119. Bouallal R, Godart F, Francart C, Richard A, Foucher-Hossein C et al. (2010) Interes of $\beta$-blockers in patients with right ventricular systemic dysfunction. Cardiol Young 20: 615-619. [Crossref]

120. Dos L, Pujadas S, Estruch M, Mas A, Ferreira-González I et al. (2013) Eplerenone in systemic right ventricle: double blind randomized clinical trial. The Evedes study. In J Cardiol 168: 5167-5173. [Crossref] 
Albakri A (2018) Heart failure in congenital heart disease: A review of clinical status and meta-analysis of diagnostic value of serum natriuretic peptides, and medical and device therapies

121. Van der Bom T, Winter MM, Bouma BJ, Groenink M, Vliegen HW et al. (2013) Effect of valsartan on systemic right ventricular function: a double-blind, randomized, placebo-controlled pilot trial. Circ 127: 322-330. [Crossref]

122. Stefanelli CB, Bradley DJ, Leroy S, Dick Ii M, Serwer GA et al. (2002) Implantable cardioverter defibrillator therapy for life-threatening arrhythmias in young patients. $J$ Interv Card Electrophysiol 6: 235-244. [Crossref]

123. Korte T, Köditz H, Niehaus M, Paul T, Tebbenjohanns J (2004) High incidence of appropriate and inappropriate ICD therapies in children and adolescents with implantable cardioverter defibrillator. Pacing Clin Electrophysiol 27: 924-932. [Crossref $]$

124. Michael KA, Veldtman GR, Paisey JR, Yue AM, Robinson S et al. (2007) Cardiac defibrillation therapy for at risk patients with systemic right ventricular dysfunction secondary to atrial redirection surgery for dextro-transposition of the great arteries. Europace 9: 281-284. [Crossref]

125. Khairy P, Harris L, Landzberg MJ, Fernandes SM, Barlow A et al. (2008) Sudden death and defibrillators in transposition of the great arteries with intra-atrial baffles: a multicenter study. Circ Arrhythm Electrophysiol 1: 250-257 [Crossref]

126. Khairy P, Harris L, Landzberg MJ, Viswanathan S, Barlow A et al. (2008) Implantable cardioverter-defibrillators in tetralogy of Fallot. Circ 117: 363-370. [Crossref]

127. Çeliker A, Olgun H, Karagoz T, Özer S, Özkutlu S et al. (2010) Midterm experience with implantable cardioverter-defibrillators in children and young adults. Europace 12: 1732-1738. [Crossref]

128. Koyak Z, de Groot JR, Van Gelder IC, Bouma BJ, van Dessel PF et al. (2012) Implantable cardioverter defibrillator therapy in adults with congenital heart disease: who is at risk of shocks? Circ Arrhythm Electrophysiol 5: 101-110. [Crossref]

129. Lopez JA (2012) Implantable cardioverter defibrillator lead placement in the middle cardiac vein after tricuspid valve surgery. Europace 14: 853-858. [Crossref]

130. Jin BK, Bang JS, Choi EY, Kim GB, Kwon BS et al. (2013) Implantable cardioverter defibrillator therapy in pediatric and congenital heart disease patients: a single tertiary center experience in Korea. Korean J Pediatr 56: 125-129. [Crossref]

131. Jordan CP, Freedenberg V, Wang Y, Curtis JP, Gleva MJ et al. (2014) Implant and Clinical Characteristics for Pediatric and Congenital Heart Patients in the NCDR ICD Registry. Circ Arrhythm Electrophysiol 7: 1092-1100. [Crossref]

132. Santharam S, Hudsmith L, Thorne S, Clift P, Marshall H et al. (2016) Long-term follow-up of implantable cardioverter-defibrillators in adult congenital heart disease patients: indications and outcomes. Europace 19: 407-413. [Crossref]

133. Dubach P, Myers J, Bonetti P, Schertler T, Froelicher V et al. (2002) Effects of bisoprolol fumarate on left ventricular size, function, and exercise capacity in patients with heart failure: analysis with magnetic resonance myocardial tagging. Am Heart $J$ 143: 676-683. [Crossref]
134. Pfeffer MA, Braunwald E, Moyé LA, Basta L, Brown Jr EJ et al. (1992) Effect of captopril on mortality and morbidity in patients with left ventricular dysfunction after myocardial infarction: results of the Survival and Ventricular Enlargement Trial. $N$ Engl J Med 327: 669-677. [Crossref]

135. Izawa H, Murohara T, Nagata K, Isobe S, Asano H et al. (2005) Mineralocorticoid receptor antagonism ameliorates left ventricular diastolic dysfunction and myocardial fibrosis in mildly symptomatic patients with idiopathic dilated cardiomyopathy: a pilot study. Circ 112: 2940-2945. [Crossref]

136. Bristow MR, Gilbert EM, Abraham WT, Adams KF, Fowler MB et al. (1996) Carvedilol produces dose-related improvements in left ventricular function and survival in subjects with chronic heart failure. Circ 94: 2807-2816. [Crossref]

137. SOLVD Investigators (1992) Effect of enalapril on mortality and the development of heart failure in asymptomatic patients with reduced left ventricular ejection fractions. N Engl J Med 327: 685-691. [Crossref]

138. Hechter SJ, Fredriksen PM, Liu P, Veldtman G, Merchant N, Freeman M, Therrien J, Benson L, Siu S, Webb G. Angiotensin-converting enzyme inhibitors in adults after the Mustard procedure. Am J Cardiol 87: 660-663. [Crossref]

139. Szymański P, Klisiewicz A, Lubiszewska B, Janas J, Barańska K et al. (2010) Endogenous catecholamine levels and function of the systemic right ventricle following atrial switch. Int J Cardiol 138: 81-86. [Crossref]

140. Babu-Narayan SV, Kilner PJ, Li W, Moon JC, Goktekin O et al. (2006) Ventricular fibrosis suggested by cardiovascular magnetic resonance in adults with repaired tetralogy of Fallot and its relationship to adverse markers of clinical outcome. Circ 113: 405-413. [Crossref]

141. Giardini A, Lovato L, Donti A, Formigari R, Oppido G et al. (2006), Gargiulo G, Picchio FM, Fattori R. Relation between right ventricular structural alterations and markers of adverse clinical outcome in adults with systemic right ventricle and either congenital complete (after Senning operation) or congenitally corrected transposition of the great arteries. Am J Cardiol 98: 1277-1282. [Crossref]

142. Oechslin EN, Harrison DA, Connelly MS, Webb GD, Siu SC (2000) Mode of death in adults with congenital heart disease. Am J Cardiol 86: 1111-1116. [Crossref]

143. Koyak Z, Harris L, de Groot JR, Silversides CK, Oechslin EN et al. (2012) Sudden cardiac death in adult congenital heart disease. Circ 126:1944-1954. [Crossref]

144. Vehmeijer JT, Brouwer TF, Limpens J, Knops RE, Bouma BJ et al. (2016) Implantable cardioverter-defibrillators in adults with congenital heart disease: a systematic review and meta-analysis. Eur Heart J 37: 1439-1448. [Crossref]

145. Bardy GH, Lee KL, Mark DB, Poole JE, Packer D et al. (2005) Amiodarone or an implantable cardioverter-defibrillator for congestive heart failure. N Engl J Med 352: 225-237. [Crossref]

146. Verheugt CL, Uiterwaal CS, van der Velde ET, Meijboom FJ, Pieper PG et al. (2010) Mortality in adult congenital heart disease. Eur Heart J 31: 1220-1229. [Crossref]

Copyright: (2018 Albakri A. This is an open-access article distributed under the terms of the Creative Commons Attribution License, which permits unrestricted use, distribution, and reproduction in any medium, provided the original author and source are credited. 